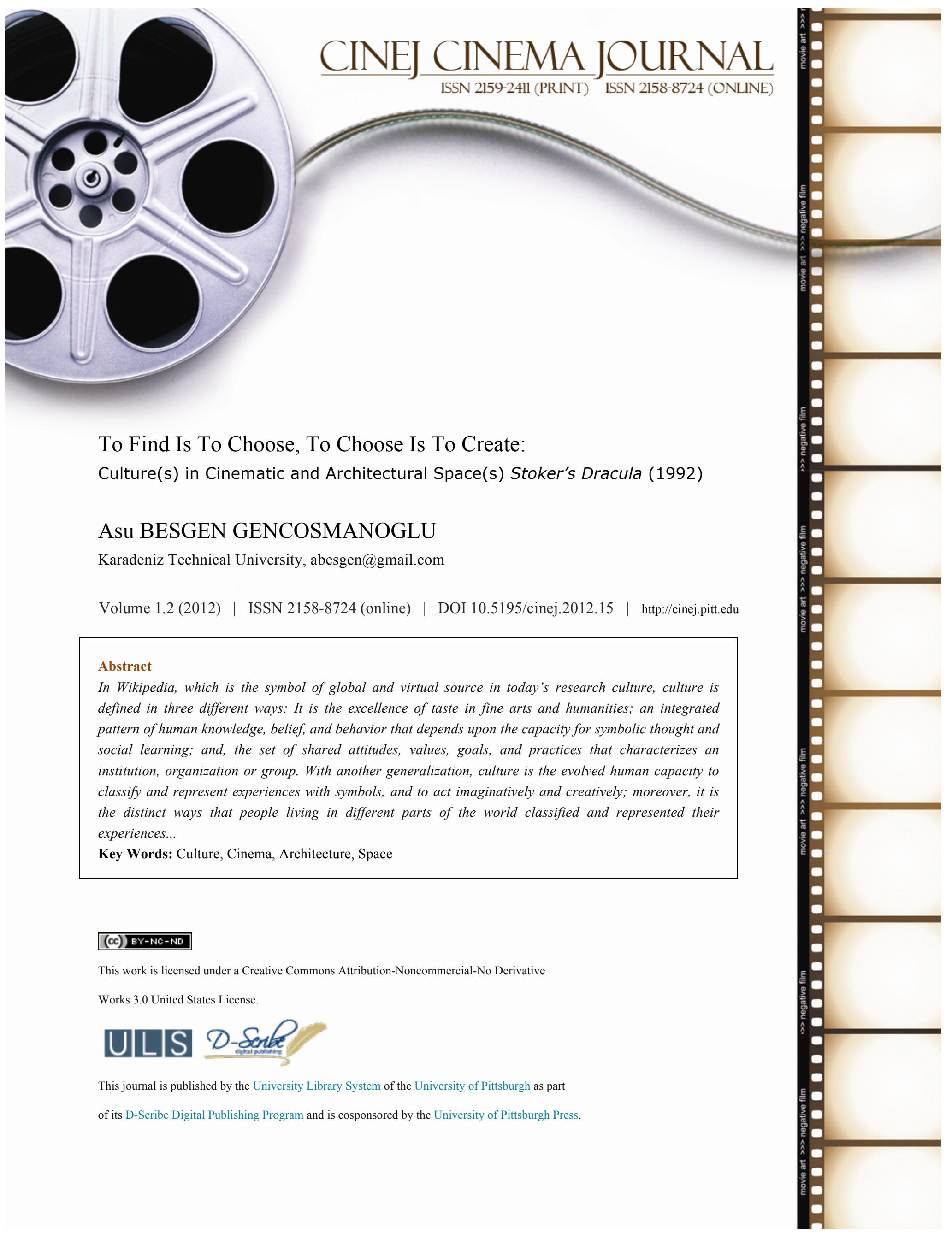




\section{To Find Is To Choose, To Choose Is To Create: Culture(s) in Cinematic and Architectural Space(s) Stoker's Dracula (1992)}

\section{To Find: Introduction}

Culture is an idea, a concept, a structure; a label that human beings produce and use for many things they contemplate on, believe in, and do.

According to Rapaport, culture is "the way of life of people, including their ideals, norms, rules, routinized behaviors" or "a system of schemes communicated symbolically from one generation to the next" or "an ecological adaptation; an effort that people make to survive by consuming various ecosystems", (Rapoport, 2005).

Culture, according to Tylor, is an extremely complex whole comprised of information, faith, art, morals, manners and customs, (Turhan, 1994). The society is a function of variables such as the humanity, the education process and the cultural content, as well as the intricate relationships between them, (Alakus, 2004), (Guvenc, 1985). As for Wissler, culture is "the lifestyle of a community", (Guvenc, 1985).

Again according to Rapaport, culture aims at "providing a life design by means of various rules that define how things are supposed to be done", "establishing a frame that adds meaning to the pieces", "defining groups, differentiating them from one another, make them separate and different from each other", (Rapoport, 2005).

No matter how varied these classifications and definitions are, the definitions of the culture concept have commonalities like being organic and dynamic. It is imperative to have a community of people or human existence in order to be able to talk about culture as a concept, (Alakus, 2004). Because culture has been and will continue to be the creative expression of communities by means of the institutions, values and experiences of the society that are shaped by symbols, language, literature, poetry, art and music.

Different cultures that have been transmitted to today by certain words like traditions, tendencies, styles, and movements help recognize, appreciate and comprehend life. In this regard, this essay that you are reading now, aims to interpret cinema and architecture as cultural indicators within the historical process, specifically in terms of "space". 


\section{To Choose: Historiography of Cinema}

Thanks to the efforts of Louis and Auguste Lumiere brothers and those numerous enthusiasts and scientists that preceded them who endeavored to make the still images move, cinema, or rather "cinematography" was officially born into life with a performance that the brothers had organized at the Grand Cafe in Capucines Boulevard in Paris, on December 28, 1895.

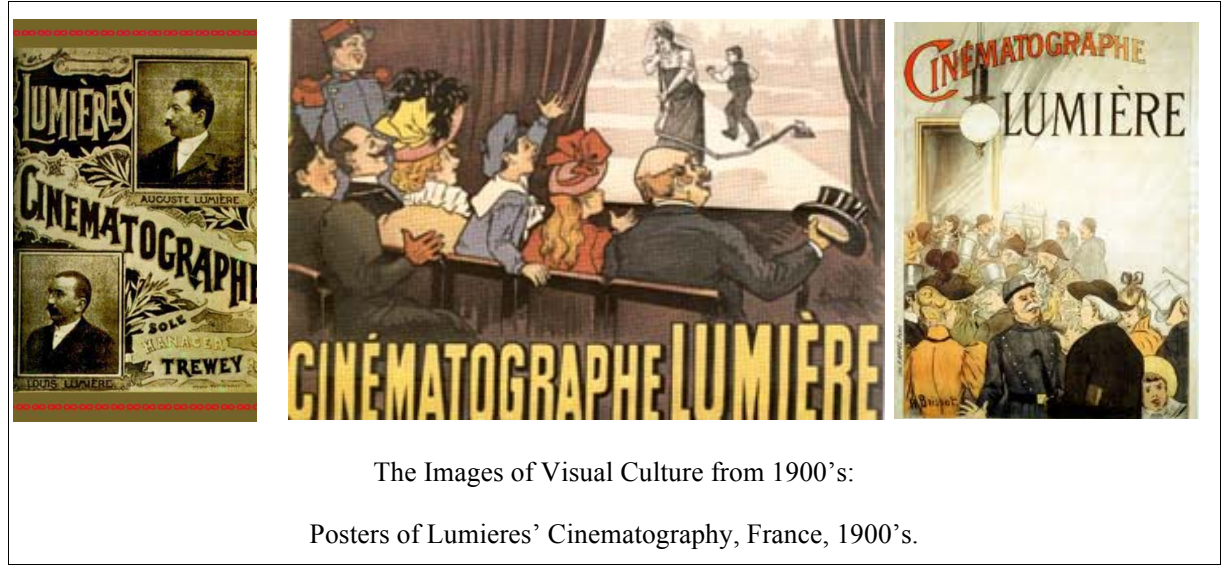

While the Lumiere brothers were organizing screenings at the bottom floor of a Parisian cafe for their "ticketed" audience, they were unlikely to be aware of the fact that they had created such an important mass communication medium by simply bringing the moving image to the people. This medium has played a crucial role in the cultural reformation, and by structurally harboring several disciplines inside, it would be called the seventh art in the future.

The steam locomotive that Luis and Auguste Lumiere had driven towards the audience in 1895 today has turned into the subway train that makes hundred and eighty miles an hour.

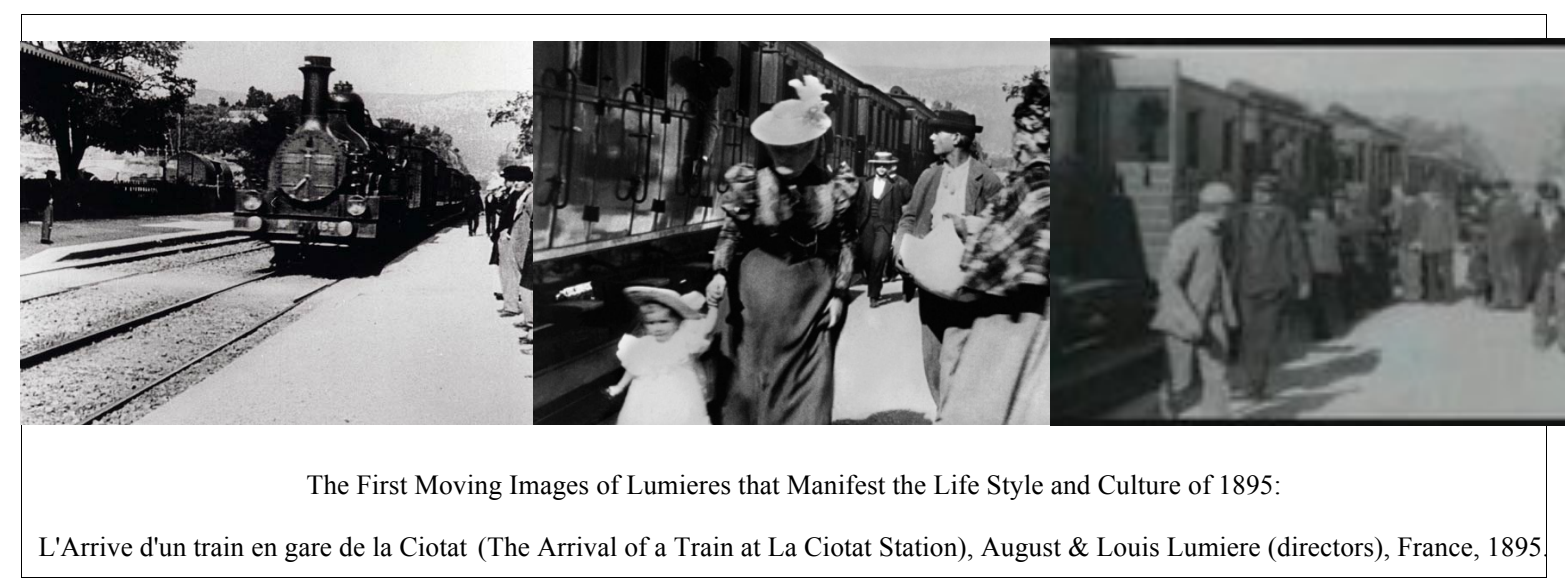

Following this event, Georges Melies founded the first film studio in 1897 and made a contribution to the beginning of cinema. 
The world cinema history was evolved around two separate poles as real and imaginary, thanks to the contributions of these two pioneers, one of whom founded cinematography while the other made films that took place in the fantasy world.

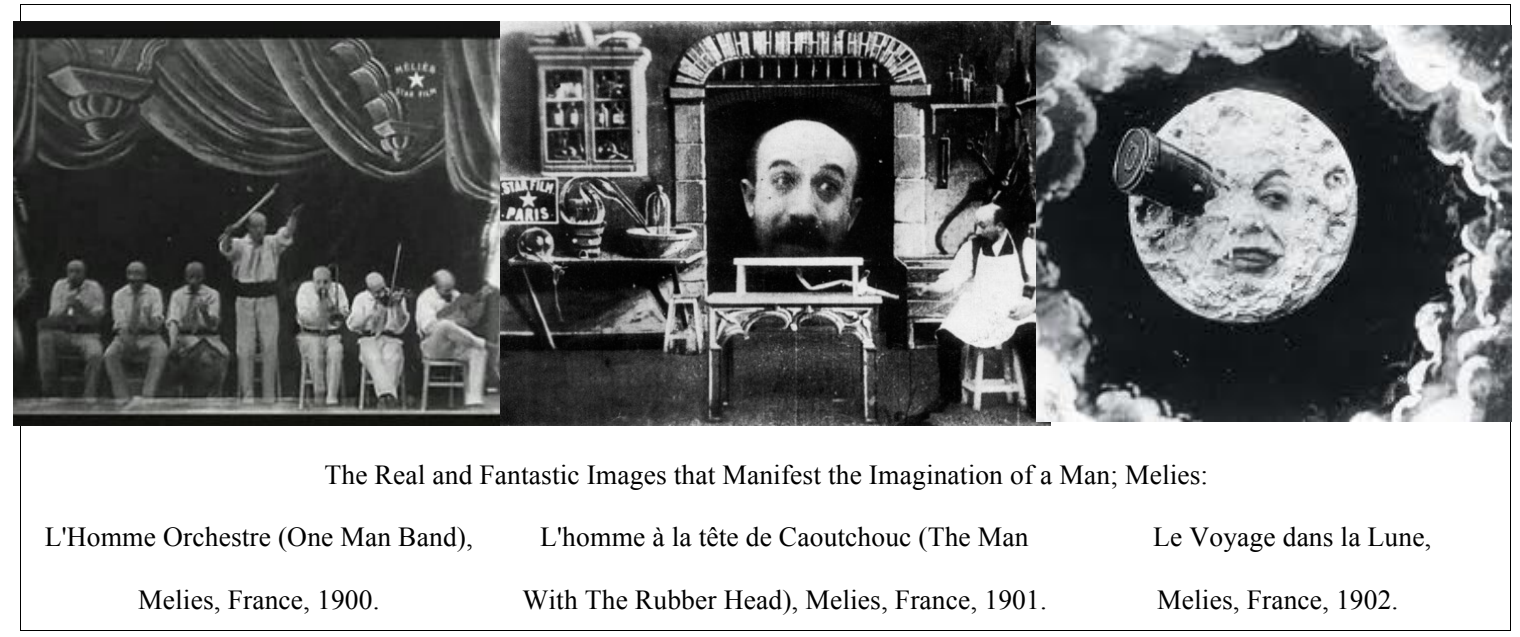

While it was Charles Pathe who made cinema reach masses of people, David Wark Griffith brought cinema the artistic quality. He left his mark on cinema as an art with all the technical and aesthetic novelties, such as montage which he brought into films.

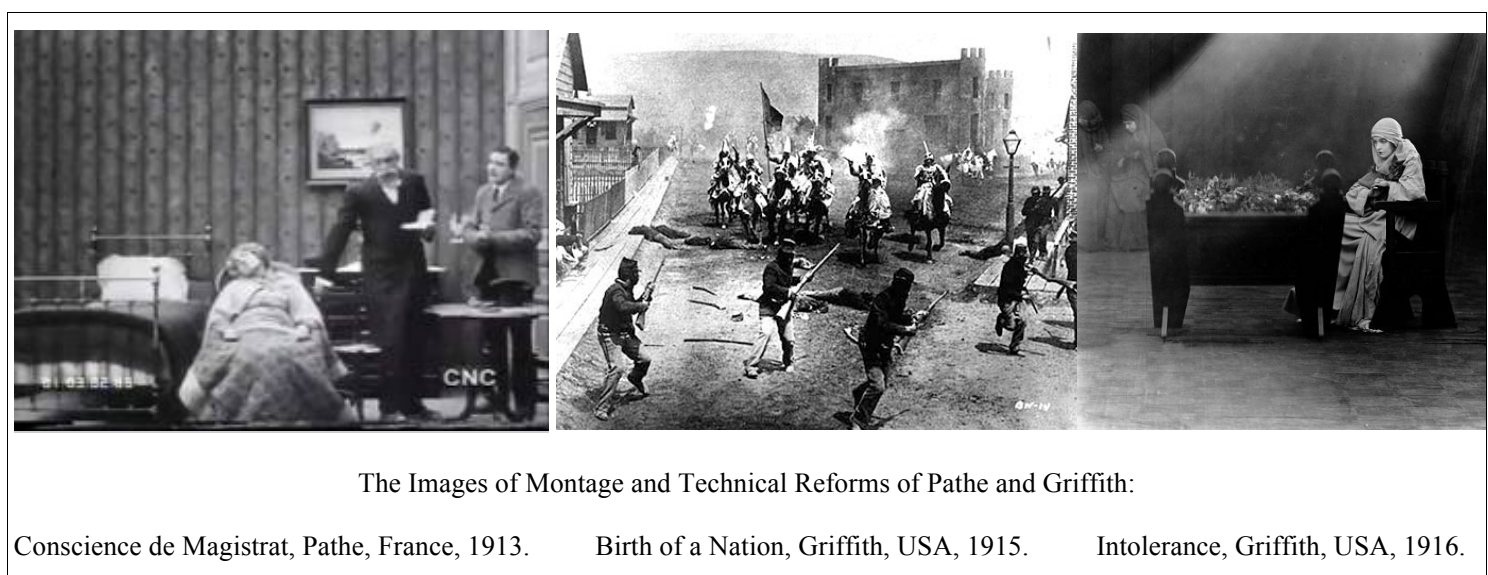

While it has been a century since these first attempts in France, dozens of social systems herewith have been developed and transformed. With the coming of industrial societies, the cultural industry has also experienced developments and the mass communication media branched out immensely. Film, as in other mass communication media, became an industry, and yet maintained its growth as a discipline of art.

The historical formation of film as art can be evaluated in seven sections, (Ergin, 2007).

1896-1912: At the end of an era where cinema evolved into becoming an economic art, feature-length films have emerged. 


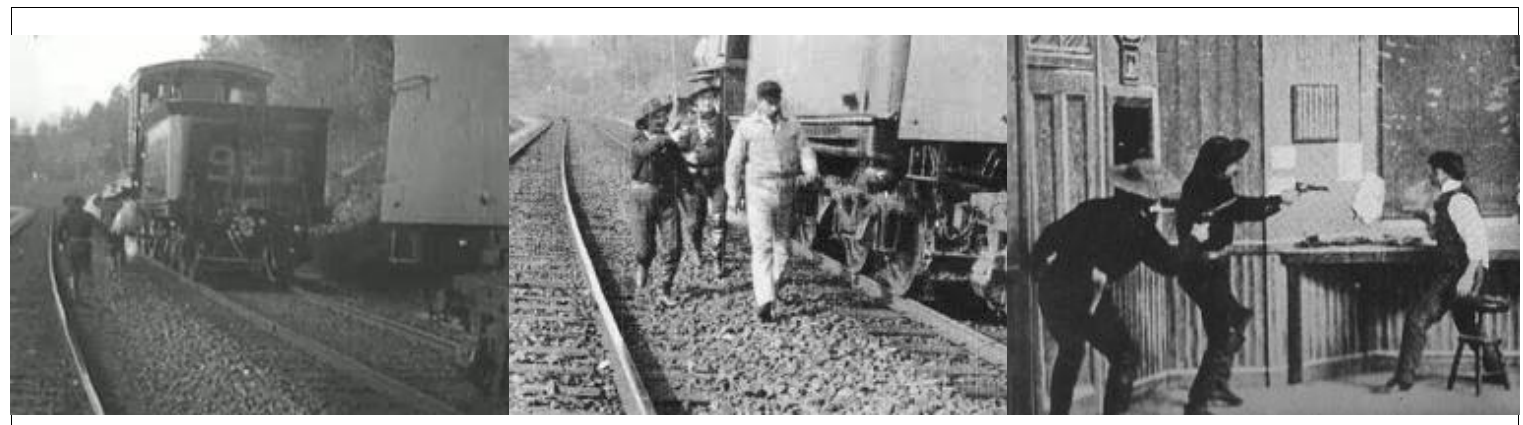

One of the First Feature-Length Movie that Manifests the Life Style and Culture of 1900's at USA:

The Great Train Robbery, Edwin S. Porter (director), USA, 1903.

1913-1927: Involves the silent cinema era.

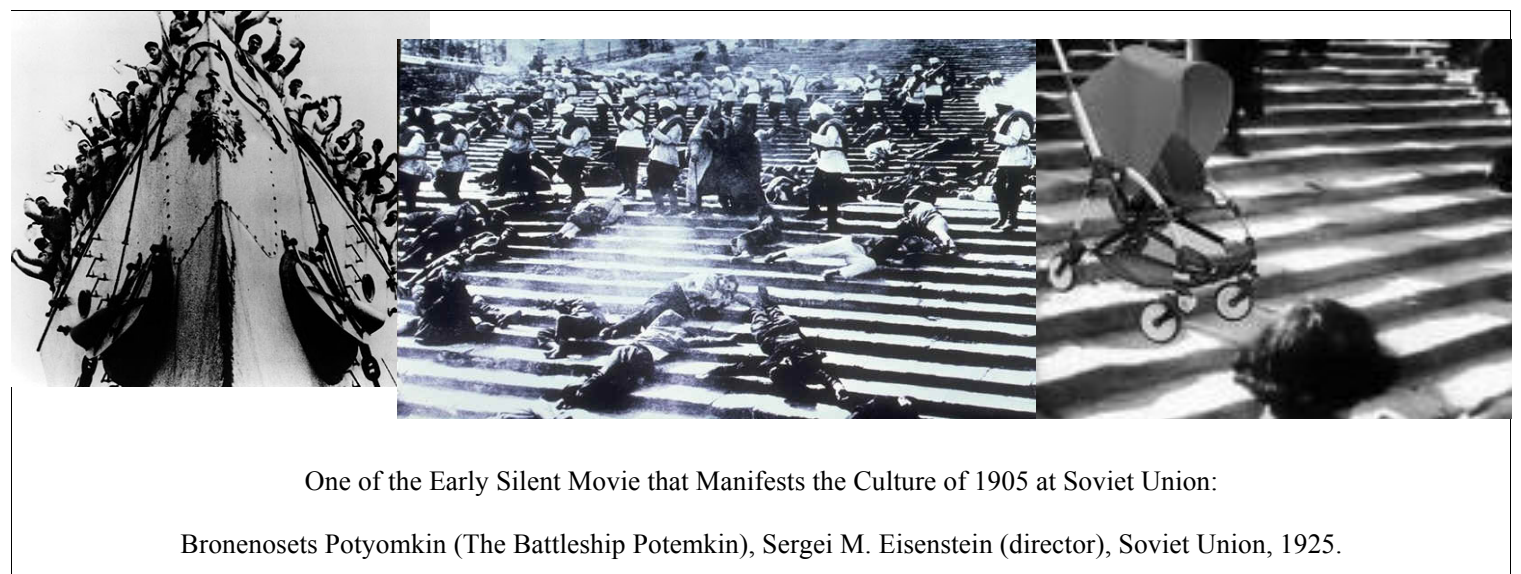

1928-1932: This economically and technologically significant era is also known as the transitional period where the number of audience has increased with the emergence of sound and color film.

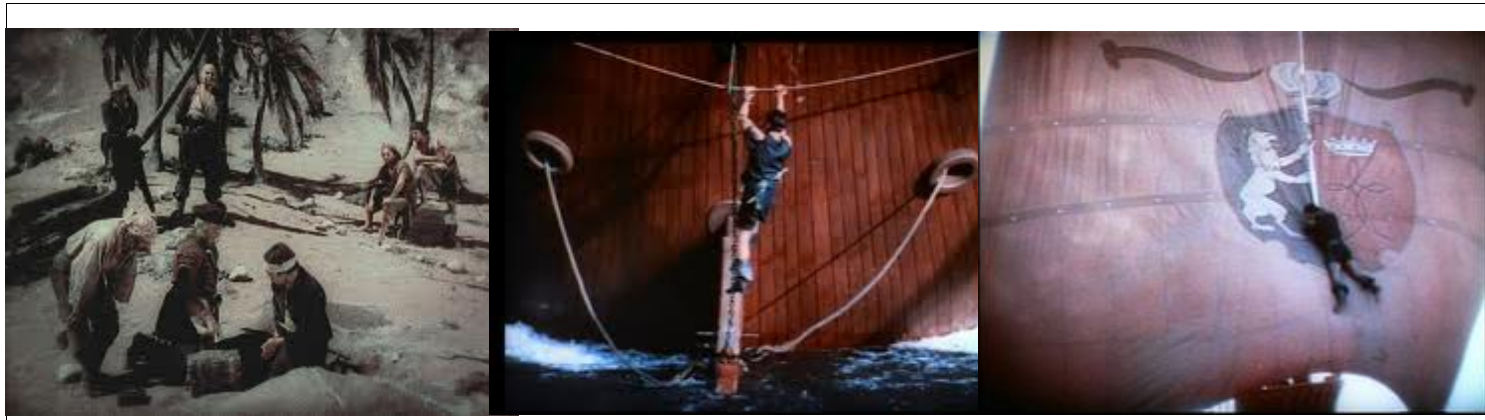

One of the First Color Movie that Manifests the Culture of Pirates at USA:

The Black Pirate, Albert Parker (director), USA, 1926.

1932-1946: The "Golden Era" of Hollywood where box office films had been made. 


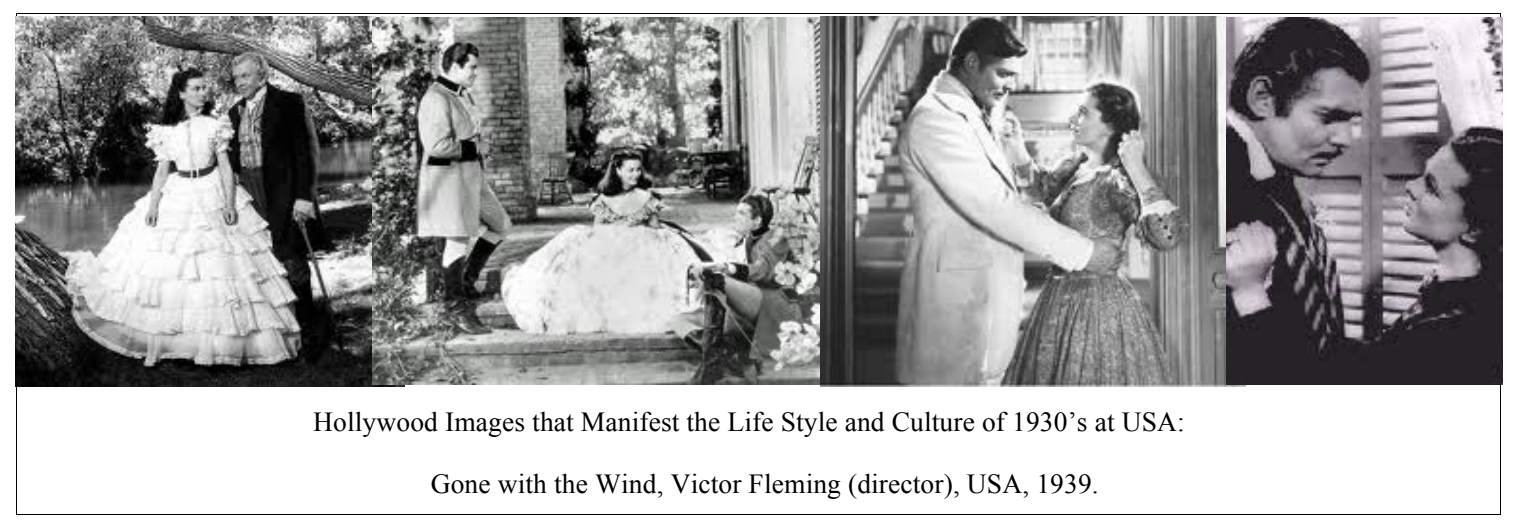

1947-1959: While Hollywood's aesthetic domination was on the decline, it had to face with another significant challenge: Television.

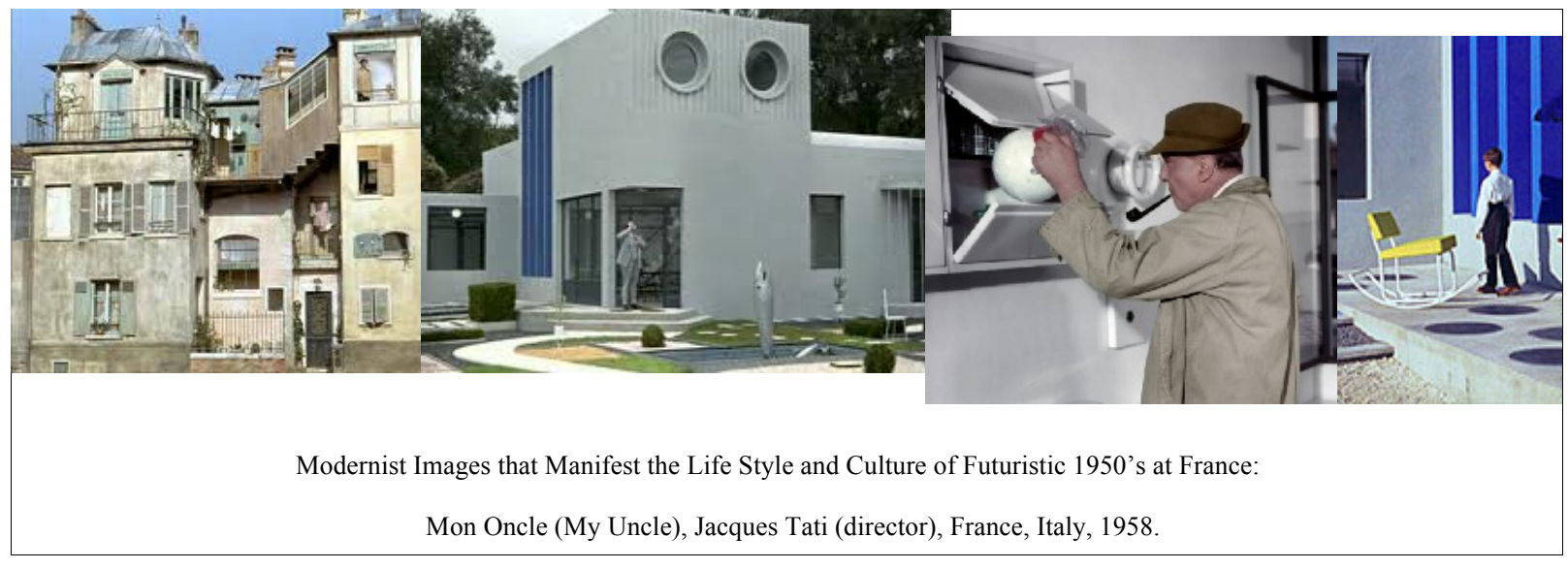

1960-1980: Emerged as a consequence of technological innovations, new economic and political understandings, French "New Wave" leaves its mark on this era.

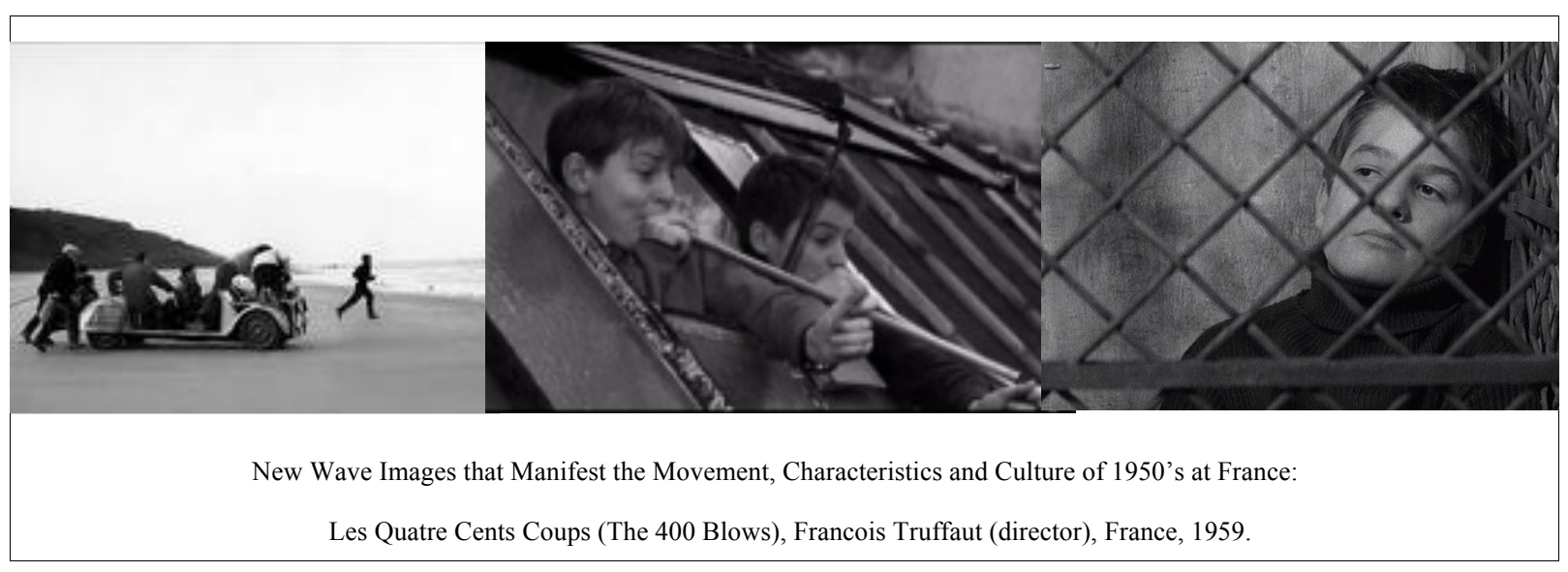

1980 and after: This is the current era that we are in, known as the end of "New Wave" and the beginning of postmodern films. 


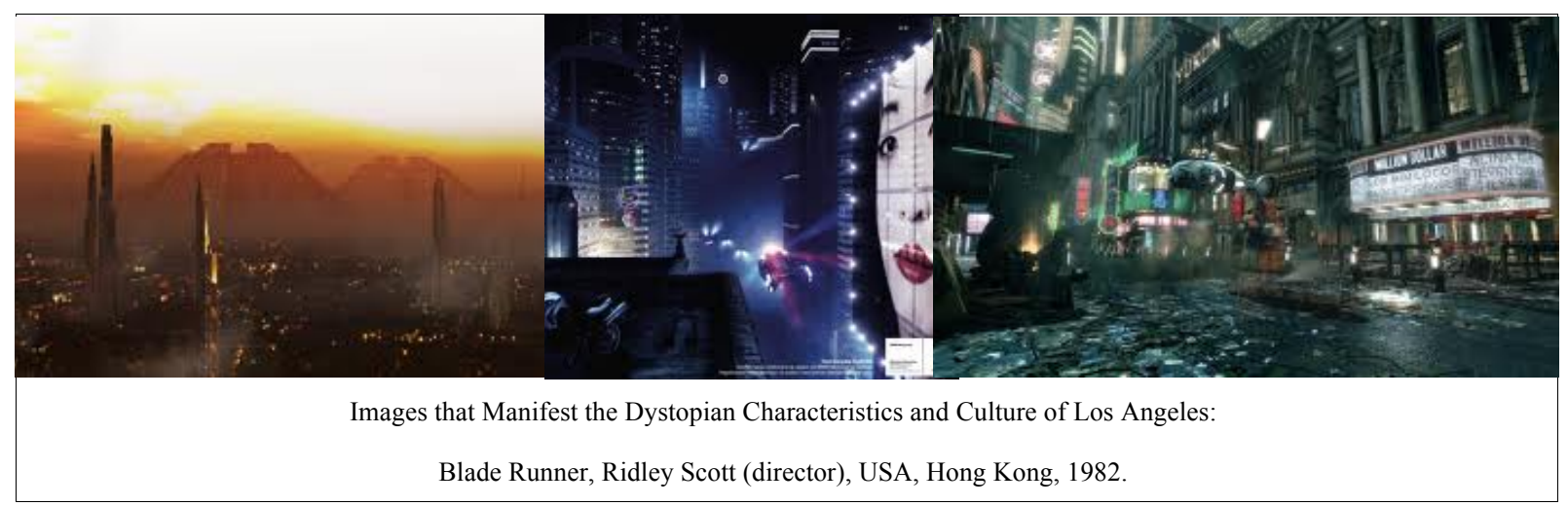

The interaction between social, political, economic, cultural, psychological and aesthetic elements play a huge role in the separation of the history of motion pictures into eras dominated by different cinematic styles. Because of its popular nature, film is able to reflect the changes in the social structure more than any other art can.

The fact that film is an audible, visible and a recordable form of art allows it to become a bridge between arts older than itself.

Architecture is one of the environmental arts that interacted with film in a way that is quite different from art, literature, theatre and music. One of the most crucial aspects of this interaction is the fact that architecture does not merely serve practical ends but it is also a visual, environmental art.

According to Monaco, "while film visually embraces people, the actual structural division, the unapproachability of film, the impossibility of direct contact, the fact that architecture insists upon this mutual interaction compared to other forms of art makes up the first stage of the relationship between architecture and cinema", (Monaco, 2000).

Again according to Monaco, "since the recording arts freely exploited their predecessors, art, music, literature, stage drama and even architecture had to redefine themselves based on this new artistic language", (Monaco, 2000).

\section{To Choose: Historiography of Architecture}

The simplest definition of architecture is that it is "the art and science of building". The existence of architecture is directly related to the humans and their needs. Every element of a constructed environment, as much as it is an architectural product, is a reflection of a specific cultural process. Definitions, pursuits and methods may change during this process; however the importance of "space" as a key concept never ceases to exist.

The history of architecture as a discipline usually starts from "Ancient Greece", and sometimes the civilizations in the "Ancient Egypt" or "Mesopotamia", and it passes through "various periods of the Western civilization" to get to our present day. This process can be positioned according to the three basic stages of human evolution, (Ergin, 2007):

Nomadic Civilization Period (10.000-7.000 B.C.): It has been claimed that architecture must have been emerged primitively in the period that comprised the last half million years of the Ancient Stone Age or the Paleolithic. In this period, due to the nomadic culture, we come across with examples of impermanent architecture such as spontaneous tents and hunts. 


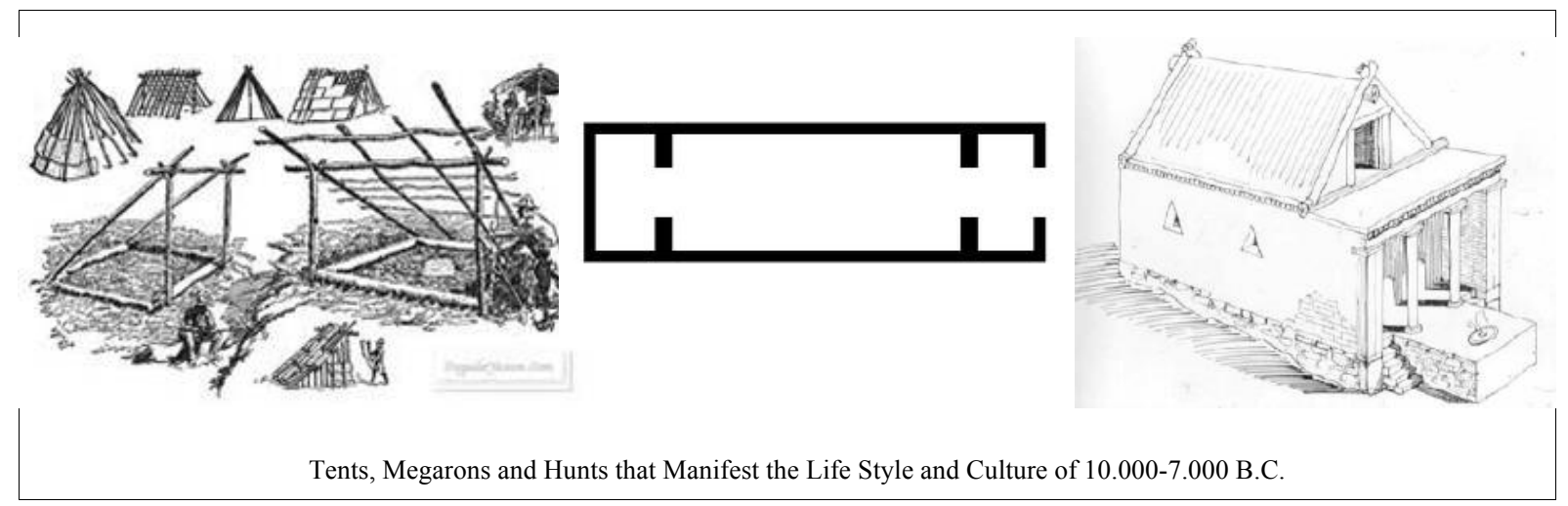

Agricultural Civilization Period (7th Century B.C.- 18th Century A.D.): In this period, the agricultural system allowed human beings to be able to settle in specific places, and therefore a form of architecture that was built permanently on the ground has emerged. Mud brick, clay, lime stone, grit stone, marble, granite and a variety of wooden materials, as well as the structural examples that involve archways, vaults and domes as a result of concrete that was developed in Rome, are the general lines that had defined this era.

Another architectural development that structurally comes into prominence is the construction style that went down in the history of architecture called the Gothic Style which started in France and quickly spread to other countries at the end of the 12th century A.D.

During the Renaissance that means "rebirth" has emerged in Italy in the 15th century A.D. precedes the growth in Europe with trade and innovations, the architecture replaced the Gothic style with Baroque and Rococo.

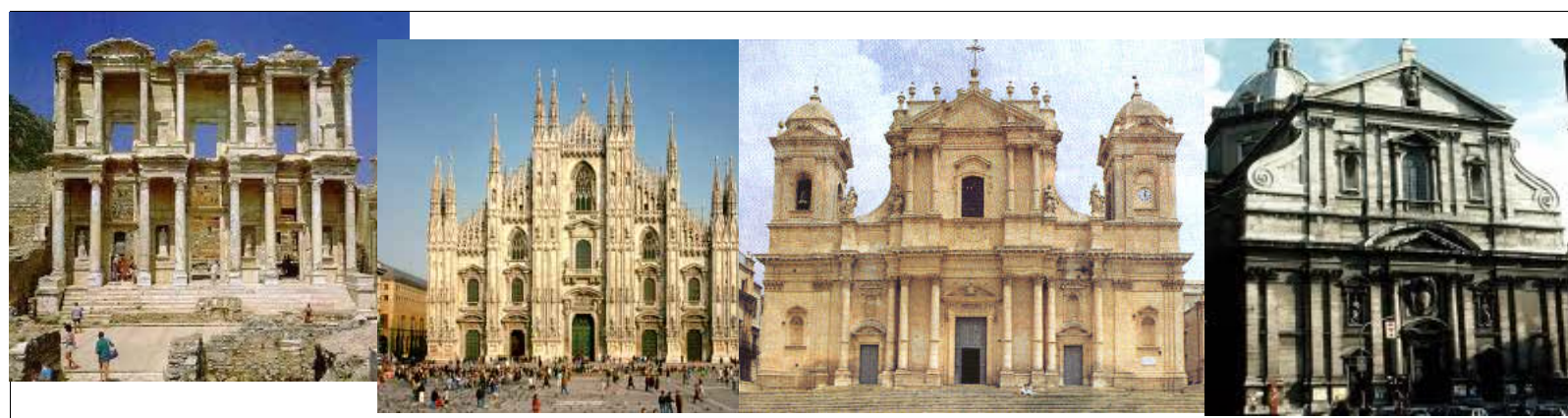

Antique, Gothic, Baroc and Rokoko in Architecture that Manifest the Life Style and Culture of 7th Century B.C.-18th Century A.C.

Industrial Period: The architecture in the industrial period is named as the Modern Architecture. When looked at the Modern Architecture since 1760s, that is after the Industrial Revolution, it is evident that the architectural structure that was planned or built in order to accommodate a specific human activity, had been built based on the master data that directly defined the activity. While the iron bridges that emerged at the end of the 18th century had been accepted as the first authentic examples of modern architecture, the Crystal Palace is the first building prototype. Architecture had reached a novel content and dimension within the framework of the sense of modern structure where concrete, steel, aluminum, and plastic materials had been reshaped and acquired the function of structuring and covering.

Parallel to these structural successes in modern architecture, modern point of views had begun to influence several architectural topics. The Rational Functionalism that was suggested and applied by famous architects such as Adolf Loos, Le Corbusier, and Mies Van der Rohe, gave birth to plenary space architecture in the 1950s. The Rationalism predicted the architectural topics to be fitted in simple and prime geometrical forms. 
Apart from that, another movement that emerged in the middle of the $1950 \mathrm{~s}$, Brutalism, stipulated the necessity of certain functions that form the structure to express themselves in any kind of a building, although it was equally committed to geometry.

Expressionism and organic architecture are two of the important tendencies that refused angular order as the irrevocable condition. The expressionist behavior that provided the architect with personal freedom in formalizing function is the first significant breakthrough that changed course of modern architecture.
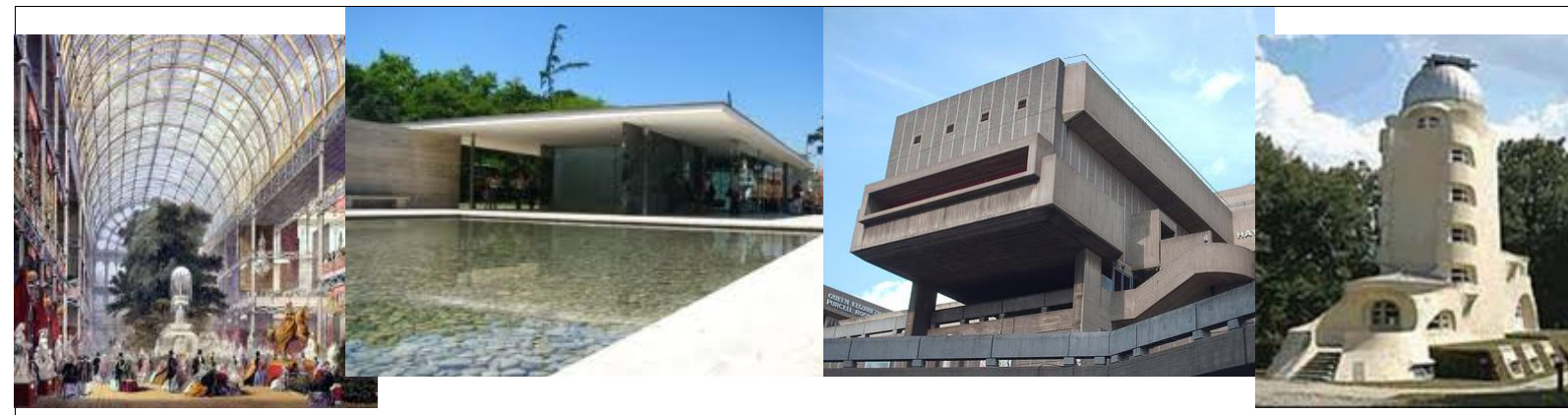

Rationalism, Brutalism, Expresyonism in Architecture that Manifest the Life Style and Culture of 19th and 20th Century.

Post modernism in architecture represents the movement that started in the 1960s, became widespread in the $70 \mathrm{~s}$ and $80 \mathrm{~s}$ and maintained its influence until today. It is a style that emerged as a reaction to the strict formalism, lack of contradiction, and the functionality of modern architecture, and brought back the ornamentation.

When it comes to the $80 \mathrm{~s}$, there were several different movements independent from each other.

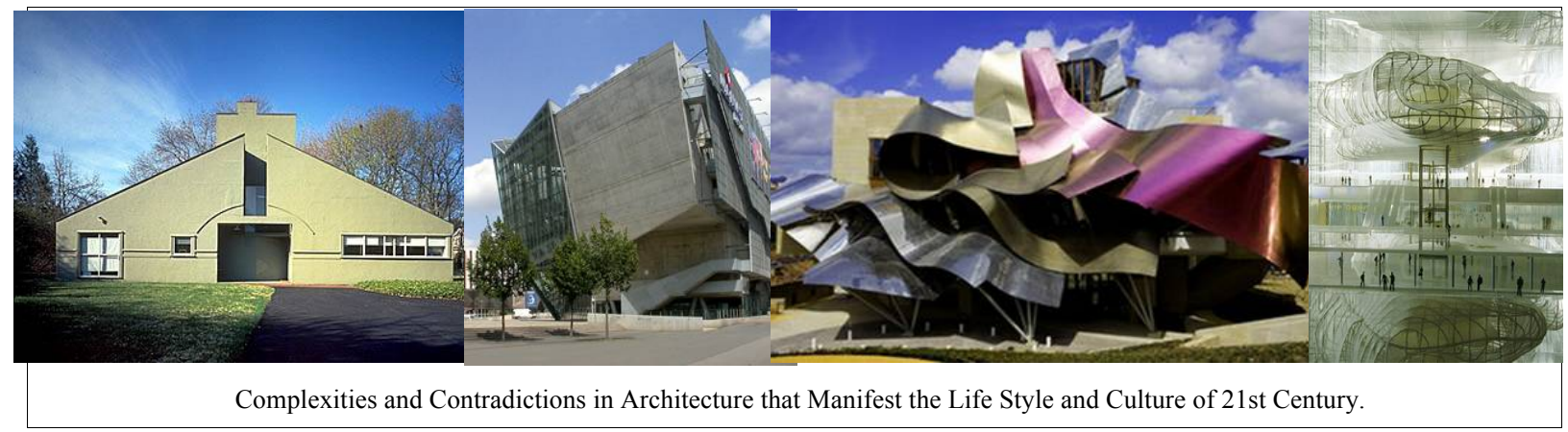

The aforementioned process as a consequence of the historical developments manifests the fact that architecture can be perceived from a very broad perspective, and its intellectual dimension, just like it is in cinema.

Architecture improves, becomes stable, complete its life and be renewed like a living organism, just like cinema.

Every architect may come to learn or acquire versatile definitions with regards to architecture based on their own experiences, much like a filmmaker.

In this regard, maintaining its continuity throughout history by means of different understandings and practices, the influence of architecture over man's relationship with the world, and its interaction with cinema that acquires the same opportunity in the process of creating new living spaces within the changing world, become inevitable. 
Because of the fact that architecture and cinema both possess the means to construct a sense of space, and that the location that is the most basic concept of architecture can be represented in cinema very close to reality, both art forms were able to raise each other throughout history.

\section{To Choose: Interaction of Cinema and Architecture:}

Even though the interaction between cinema and architecture has been defined as visual and intellectual, according to Tanyeli, there are three types of relationship-interaction between cinema and architecture, (Tanyeli, 2001):

First relationship is the definition that cinema identifies as "unbuilt" and "a virtual architectural area" that is not being used in reality.
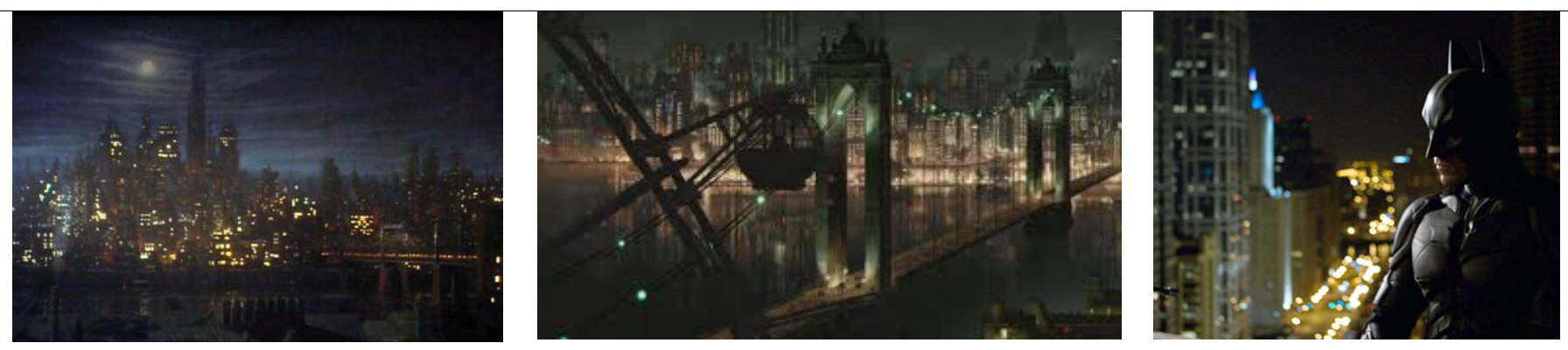

The Virtual Images that Manifest the Characteristics and Culture of the Future:

Batman Movie Series, Tim Burton, Joel Schumacher, Christopher Nolan (directors), USA, UK, 1989-2012.

The second relationship is the fact that cinema reproduces the "real" architectural spaces in its own virtual universe.

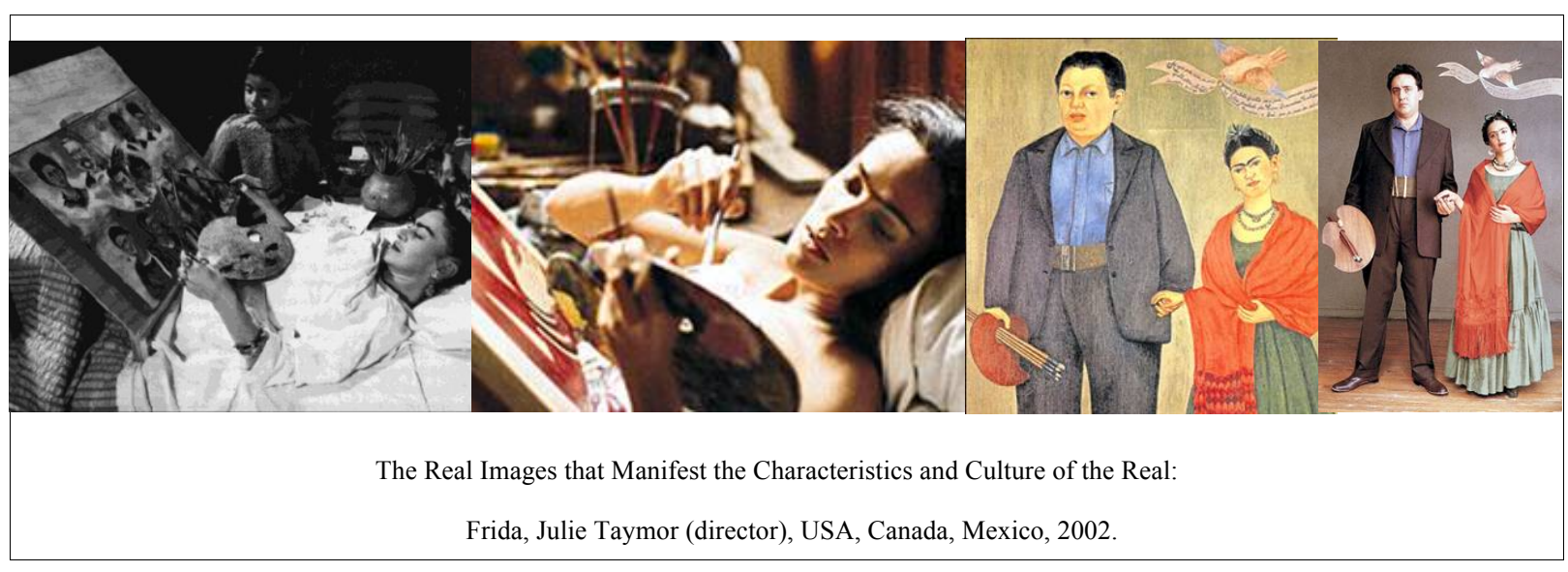

The third relationship is about cinema taking "the architect as a personality and his/her architectural activities" as its subject within the fiction. 


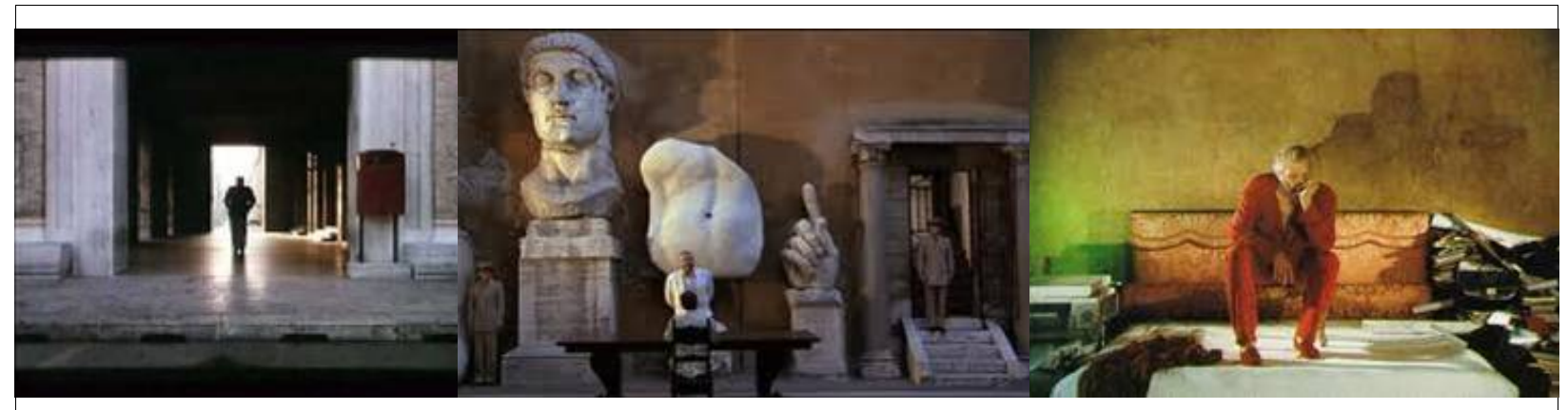

The Real Images that Manifest the Characteristics and Culture of the Architect:

The Belly of an Architect, Peter Greenaway (director), UK, Italy, 1987.

Looking at the interaction of cinema and architecture from these three perspectives is insufficient in our understanding of and interpreting both areas. In this sense, it is going to be valuable to elaborate this interaction from different details.

The first interaction of cinema with architecture can be defined as "methodological-terminological interaction". Both cinema and architecture completes similar phases during the processes of production; they use similar methods until the application process. Both arts begin in the mind, later to be transferred on to the paper, the pieces are composed and they experience several changes until they are combined to form the final product.

When we look at the visual vocabulary of film, the terms such as "frame", "camera angles", "point of view", "perspective", "shooting scale". "light-color", and "time", are also used in architecture.

Nowadays, cinematic terms like "montage", "screenplay", "framing" have become widely used by architects.

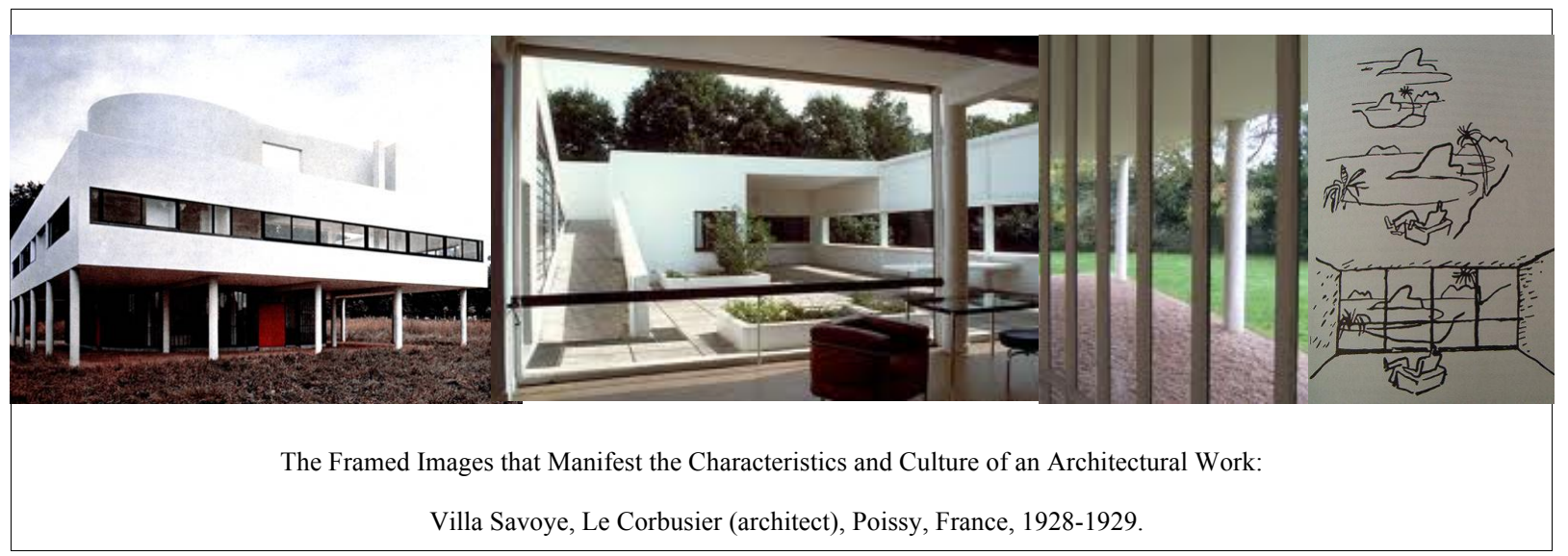

The methodological and terminological interaction between cinema and architecture is illustrated in Le Corbusier's use of "framing", (Vidler, 2001); Jean Nouvel's use of "montage" and "framing"; Rem Koolhass' use of "screenplay"; Bernard Tschumi's use of "screenplay", "montage", "framing", "superimposition", "juxtaposition", "sequence", "cut", "movement", "event” and "program”, (Pelissier \& Tschumi 1999), (Tschumi, 2000) are only some examples while explaining their designs. 


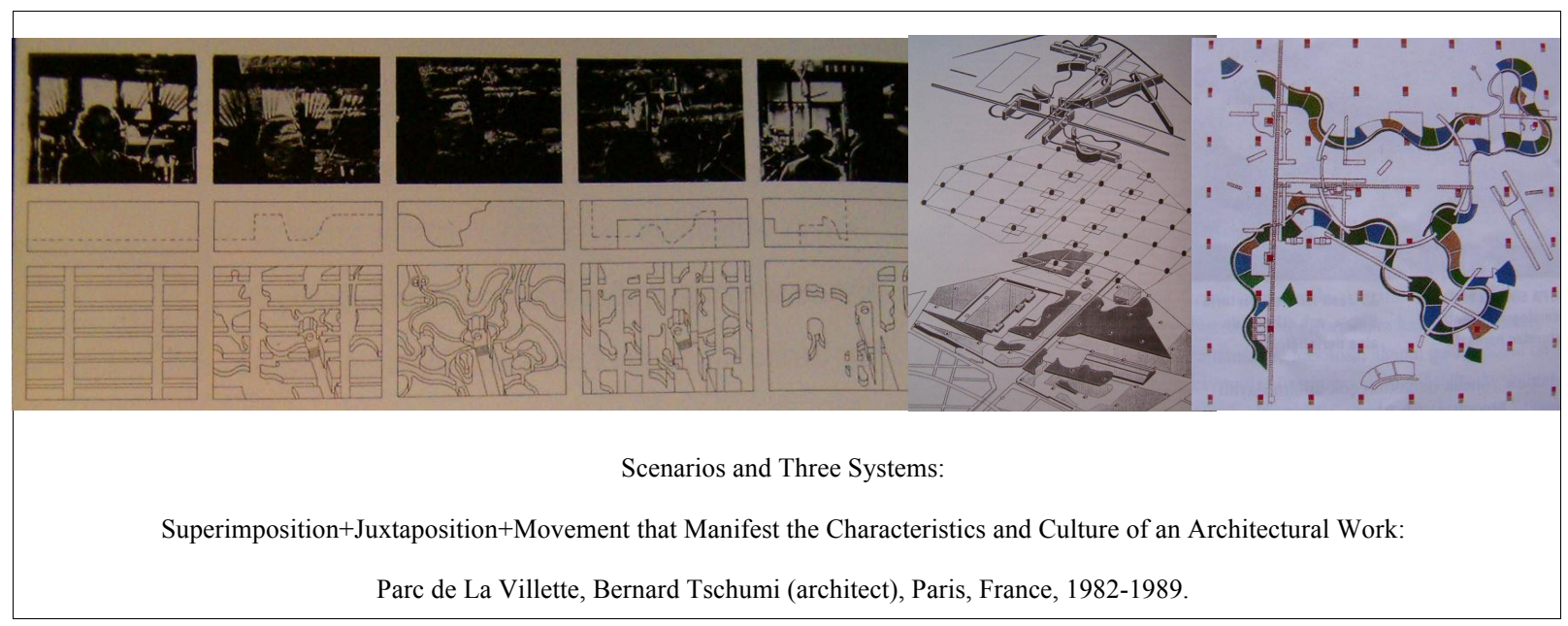

Eventually, the visuality that is used by cinema and architecture; commonalities in the terminology such as "movement", "montage", "frame", "cut", "composition", "light", "space", "sound" among others; and the methodological similarities that this terminology displays, make it inevitable for these two arts to interact with each other in their final products and to establish cultural links.

Another important aspect of cinema's interaction with architecture is that "cinema provides architecture an experimental environment". As much as cinema is an environment that can be employed to be able to create an architecture that otherwise does not exist, it is also an area that can expose the use of architecture by different users or for different goals, as well as demonstrate how the structures can be reused for future generations and events.

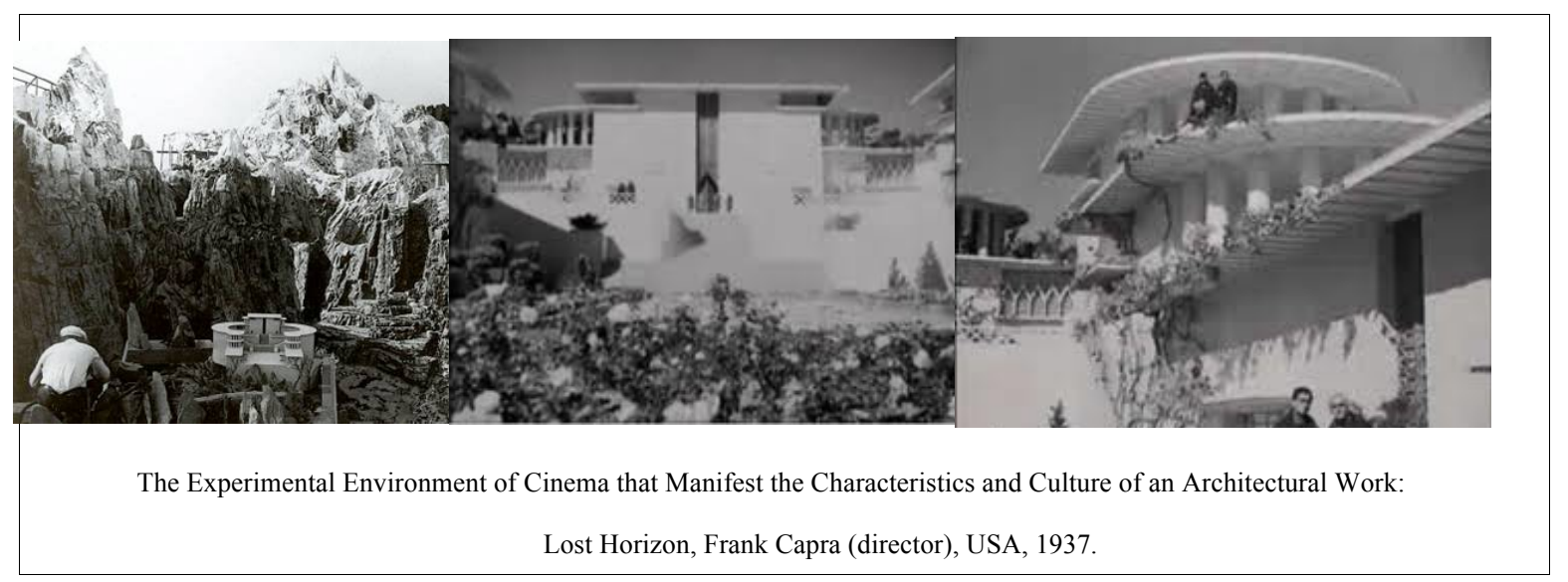

Cinema provides architects with a platform where the current architecture and the lifestyle it defines can be investigated, the future problems that it may bring are exposed or in which direction the innovative architectural forms are going within the utopian films are discussed. 


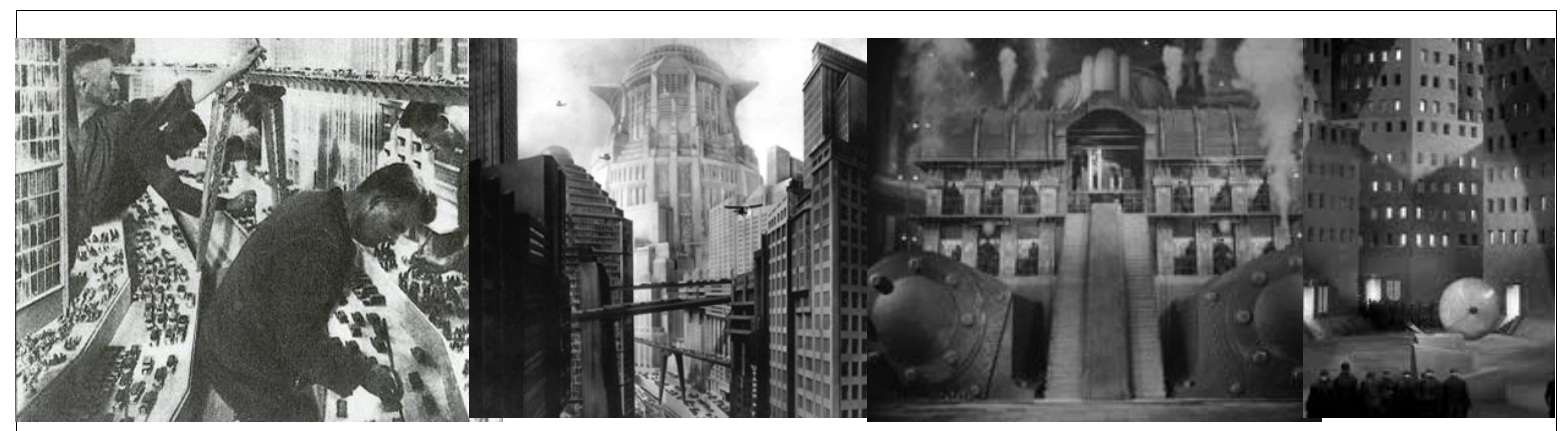

The Experimental Environment of Cinema that Manifest the Characteristics and Culture of an Futuristic Architectural Environment:

Metropolis, Fritz Lang (director), Germany, 1927.

As a consequence of Bernard Tschumi's late night meeting with filmmaker Eric Rohmer and actor Boris Karlof, around four a.m. in the morning, a structure has emerged by the movements of the character in Frankenstein (movie) and the transformation of the projections of these movements into walls and locations. When Boris Karlof said this structure might as well be his home, the idea on how to turn a movement chart into architecture had been suggested. Directly from this example, it is clear that a film can be used as the most efficacious influence in forming a design, (Tschumi, 2000).

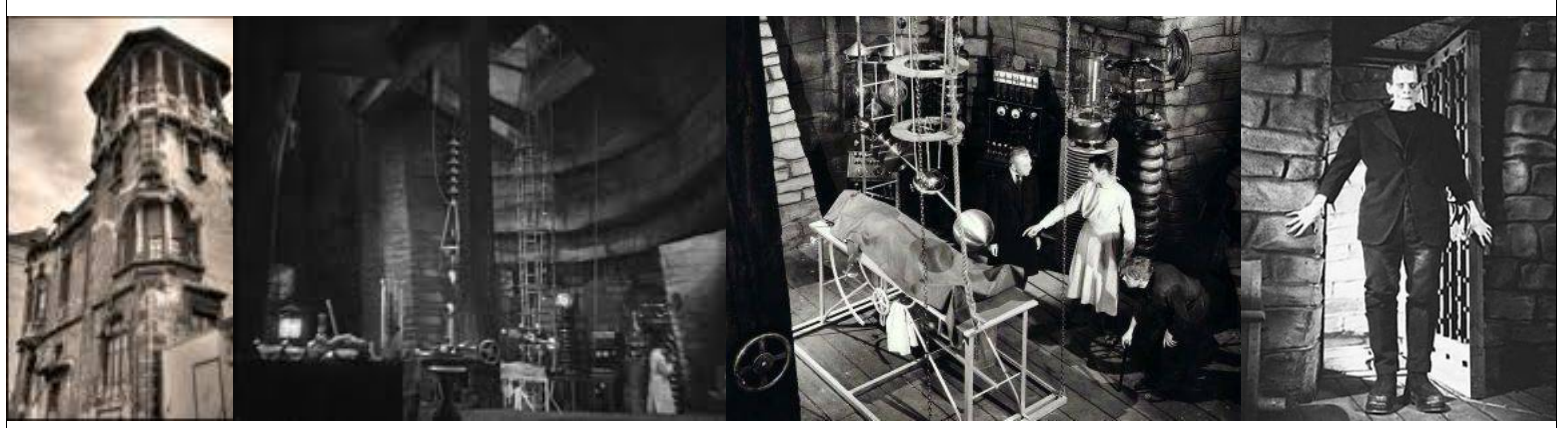

The Experimental Environment of Cinema that Manifest the Interactional Culture of Cinema and Architecture:

Frankenstein, James Whale (director), USA, 1931.

It can be claimed that cinema possesses an educational aspect for architects in terms of acknowledging the perception of places and meaning-location relationship through film reading, as well as appreciating the components and methods that are used with regards to space creating techniques. In this respect, it can be said that there is an "educational interaction" between both arts.

Additionally, film appears to have a role in raising public awareness towards architecture and spaces, as well as in educating them about conscious use of spaces.

"To work on the poetic architecture of cinema will help the architects in rediscovering the symbolic measures of life and their own artistic forms", Juhani Pallasmaa (Architect), (Pallasmaa, 2001).

A city can be viewed from the bird's eye view, a whole city can be perceived in one single frame, or quite the opposite a small room can be re-experienced like a city from an ant's perpective. 


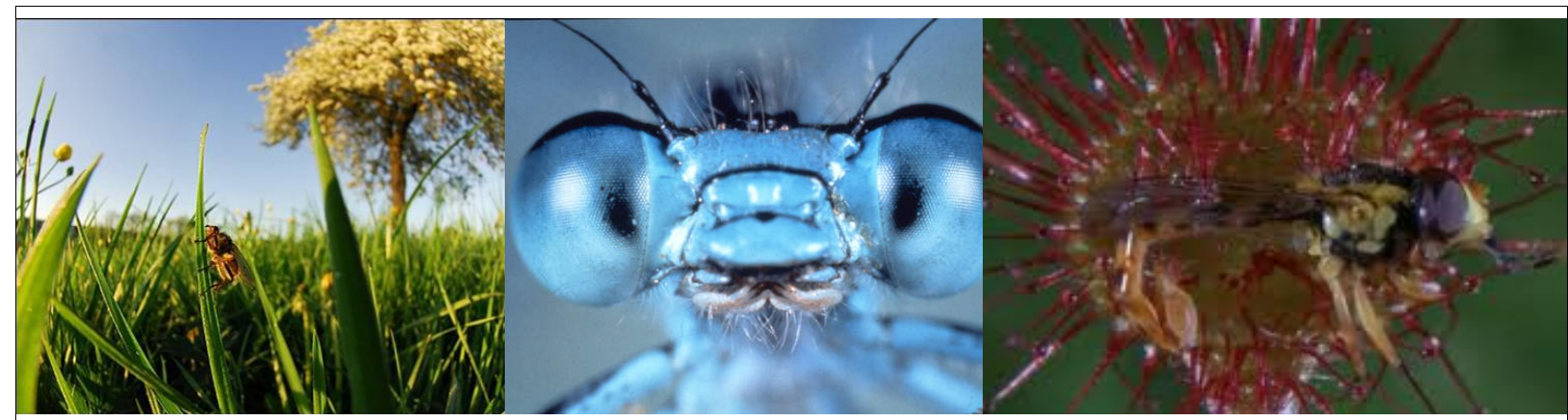

The Educational Environment of Cinema that Manifest the Interactional Culture of Cinema and Architecture at Micro Scale:

Microcosmos, Claude Nuridsany, Marie Pérennou (directors), France, Switzerland, Italy, 1996.

At this point, space is perceived by means of such scales that would normally be impossible from a person's point of view. There is no doubt that cinema will be very useful for architectural students in terms of comprehending concepts like city, space, light, time, movement and scale, as well as imagining spatial features.

"The re-representation of the city in a film, a novel or a poem helps us in analyzing its political, philosophical and artistic levels without mixing their intertwined envelopes; creates a form of knowing", Akbal Sualp (Psychologist and sociologist), (Sualp, 2004).

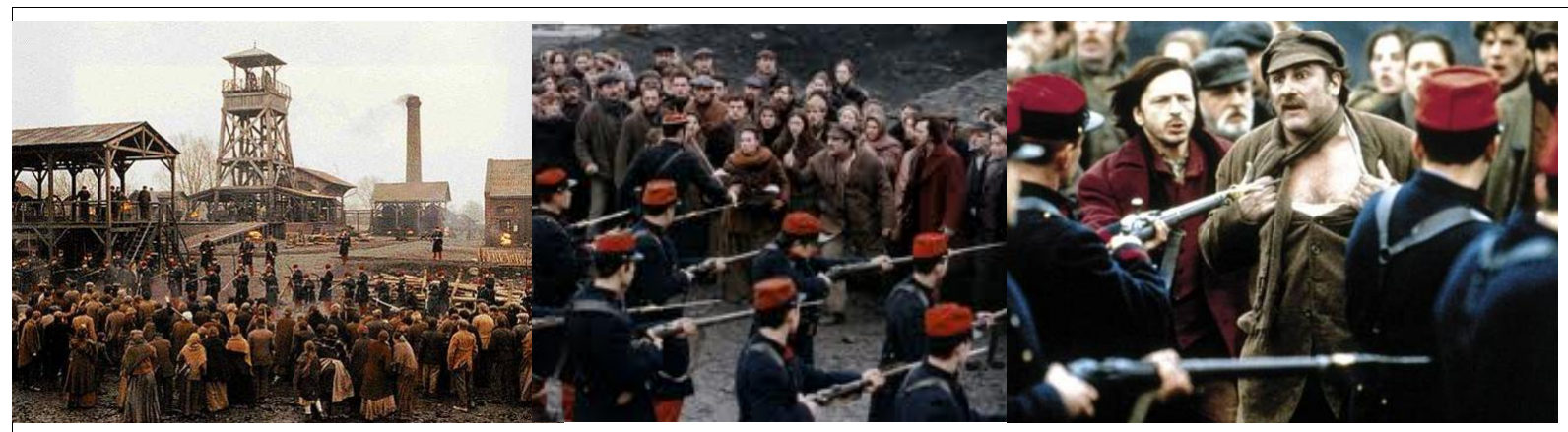

The Educational Environment of Cinema that Manifest the Interactional Culture of Cinema and Architecture at Macro Scale:

Germinal, Claude Berry (director), France, Belgium, Italy, 1993.

When we look at the backgrounds of prominent directors, producers, art directors or set designers, we see that they have somehow studied architecture at some point in their lives. For instance, Ken Adams, who had worked with Stanley Kubrick, says he met the director Vincent Korda when he was only fifteen and studied architecture by taking his advice. This shows us that an architectural background, knowing the styles of different periods, provides convenience in designing functional and agreeable film sets, (Ettedgui, 1999).

It is obvious that, people who work in the film business, like Henry Bunstead who worked with names like Martin Scorsese and Clint Eastwood; Dante Ferrerri who worked with Pier Paolo Pasolini, Federico Fellini, Terry Gilliam; Dean Tavoularis who worked with Francis Ford Coppola, Roman Polanski; Ben Van Os who worked with Peter Greenway; John Beard who worked with Martin Scorsese and Terry Gilliam; Dan Weil who worked with Luc Besson, have all either studied architecture or worked in the architecture business, (Ettedgui, 1999).

"Cinema was able to express modern architecture as opposed to photography and other representative technologies that failed to do that, and it helped architecture to expand and to be interpreted. When there is 
nothing tangible at hand, the thoughts of modernity in architecture -in the form of expressing praise and fear- have been embodied in the light and shadow, scale and movement of an environment”, Ipek Tureli (Architect), (Tureli, 2001).

In this regard, it can be claimed that the "movements" have played an important role in the interaction of cinema and architecture. For example, the periods when film had become more important and stronger, have overlapped with movements like expressionism and modernism, and it is observed that the interaction of cinema and architecture has grown stronger.
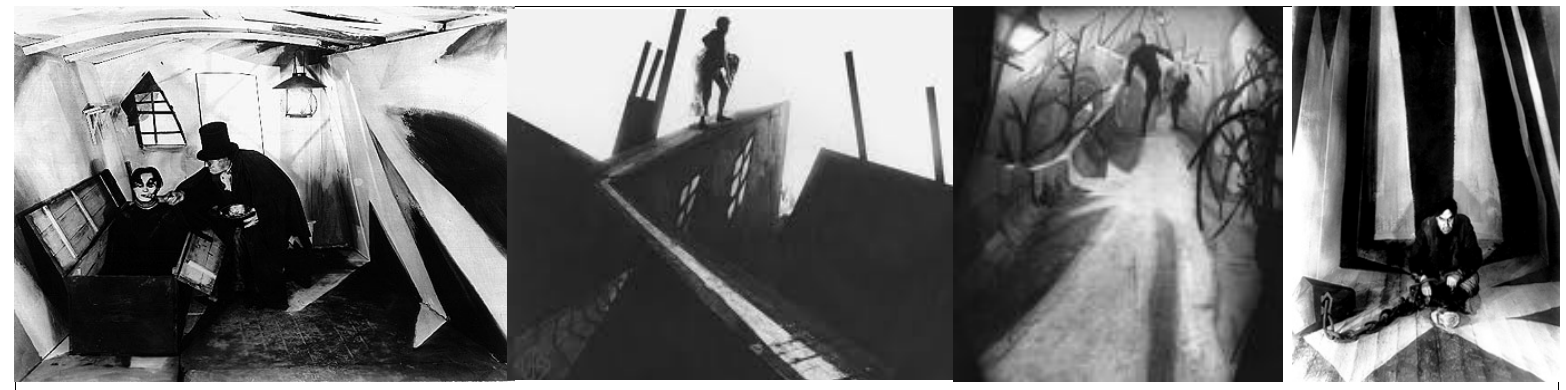

The Expresionist Images that Manifest the Characteristics and Culture of 1920's:

The Cabinet of Dr Caligari, Robert Wiene (director), Germany, 1920.

"The distinct influence of cinema on modern architecture is undeniable; on the other hand, modern architecture channels its aesthetic aspect into cinema", Robert Mallet-Stevens (Architect), (Vidler, 2001).

Another title of this interaction is "the nature of the document being in cinema and architecture". Both architecture and cinema stand out as historical evidence and document. This documentary quality opened up another area where they mutually interact.

Every structure mirrors the time it was built. It reserves the social, cultural, religious features of the period, the geographical and climactic conditions of the region. These features have come to be known as essential within the world of cinema, and this attitude makes the use of architectural information in the films as mandatory. The persuasiveness of a film depends on the architecture, costumes, music that is used, as well as the human behaviors that use and shape the locations.

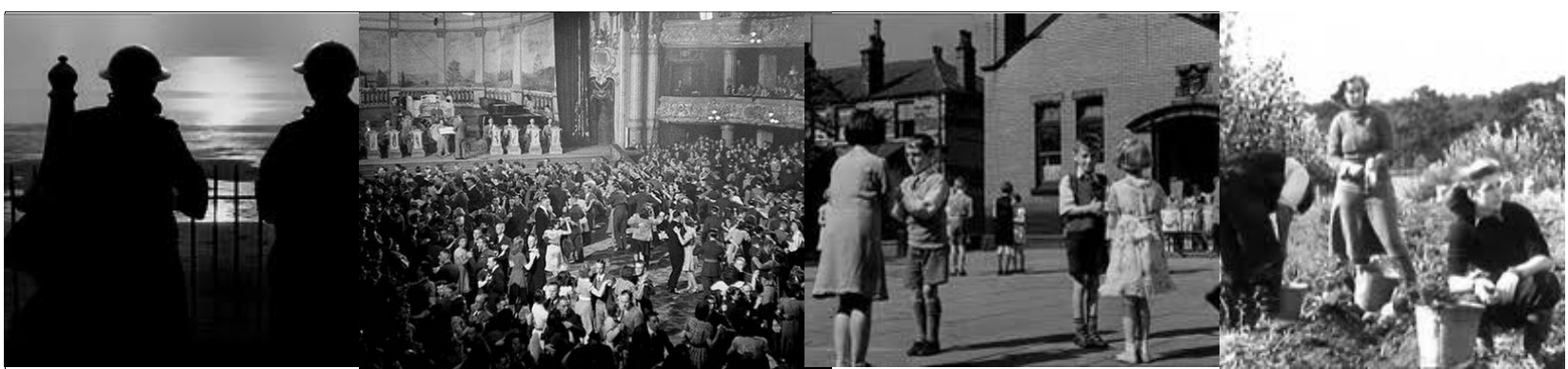

The Documentary Images that Manifest the Characteristics and Culture of 1940's at Britain:

Listen to Britain, Humprey Jennings, Stewart McAllister (directors), UK, 1942.

The Housing Problems (1935) movie, shots on location, has displayed the situation in the suburbs, and defined the architecture of the time, as well as the housing problems; in movies like When We Built Again (1942), A City Reborn (1945), Proud City (1945), the information on how the cities and architecture would look like had been discussed. 


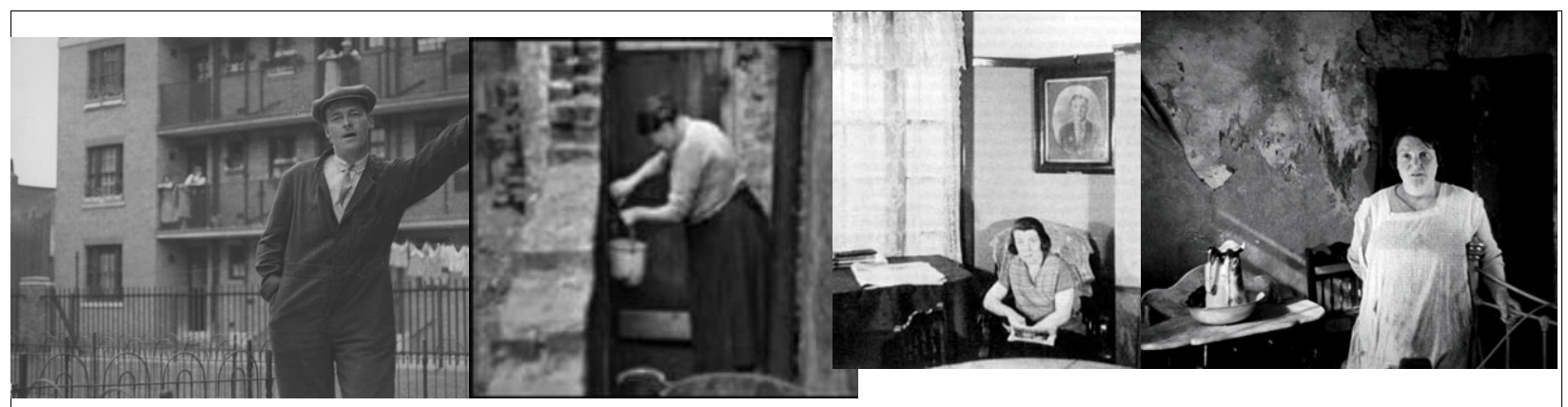

The Documentary Images that Manifest the Characteristical and Cultural Housing Problems of 1930's at Britain:

Housing Problems, Arthur Elton, Edgar Anstey (directors), UK, 1935.

While establishing its products, both cinema and architecture would need some common components or they are influenced by these elements. In this regard, "the use of common elements" in both arts can be considered as an interaction. These common elements are light, space, model, sound, nature, and human. However, goals and types of employing these elements sometimes show similarities and differ from one another. For instance, cinema uses human as actors, as well it serves them. Architecture does serve human as well, and because of that, it uses the human as a scale.

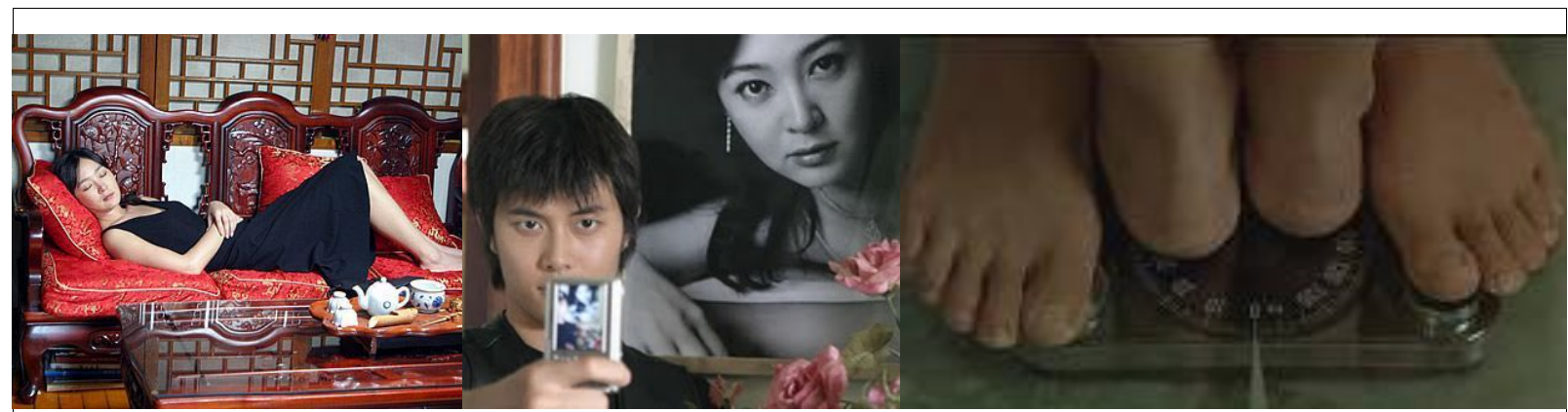

The Human Images that Manifest the Characteristics and Culture of Using Common Elements at Cinema and Architecture: Bin-jip (3-Iron), Ki-duk Kim (director), South Korea, Japan, 2004.

Cinema and architecture are the indicators of visual culture. In this respect, the phenomenon of "space", that we come across with in both areas as a common and pivotal element becomes the mirror of visual culture.

\section{To Create: Culture(s) in Cinematic and Architectural Space(s)}

While space is a tool in cinema and in other arts, art is used in architecture in order to create space. This feature is one of the most important qualities that separate the cinematic space from the architectural space.

The goal in cinema is not defining or creating the space. Space is a tool that is being used in order to reach the goal. Space is one of the inevitable elements like screenplay, music, light, and actors. Space in cinema as being a representation cannot carry all the features of an architectural space.

Architecture addresses the five senses: seeing, smelling, touching and even tasting. The positions of objects within the space, distances and the hierarchy between them, their colors, surfaces, textures, relationships, 
shadows and their edges, sounds, musics and their acoustics, they all create and define the space. On the other hand, the camera can only record two of these senses: The pictures and the sounds.

"We cannot smell, touch or taste films; but we certainly hear them as the way we see them", Ian Jarvie (Philosopher), (Jarvie, 1987).

At this point, it can be said that space is transformed into images and sounds in film.

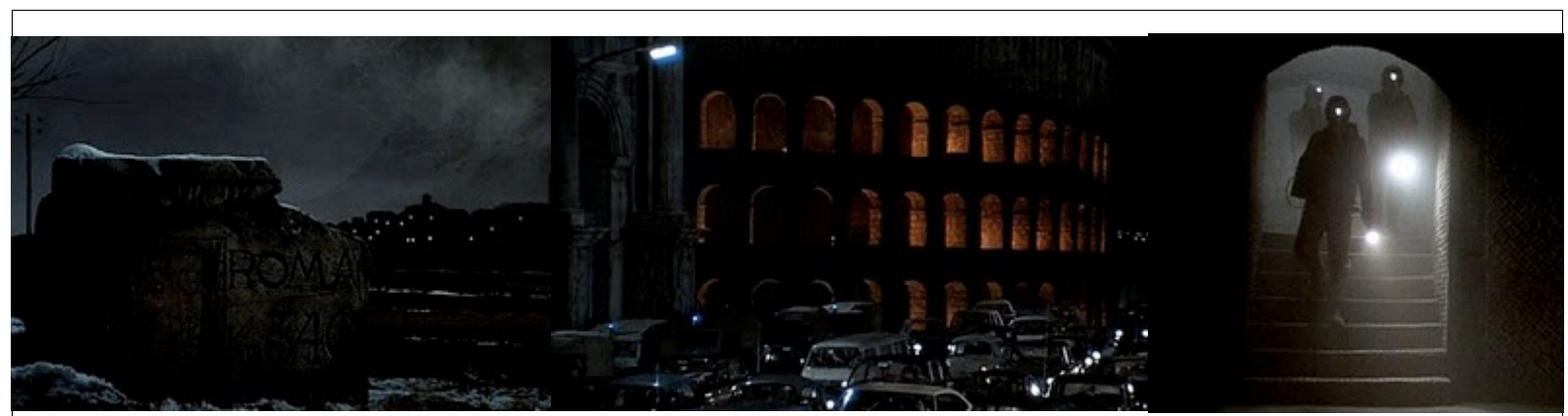

The Spaces that Manifest the Characteristics and Culture of a Period at Cinema and Architecture:

Roma, Federico Fellini (director), Italy, France, 1972

"Space is never empty; it always contains a meaning", Henri Lefebvre (Sociologist), (Dear, 1994).

The cinema takes advantage of this quality of space. "Both architecture and film explain the space that is lived in. These two forms of art create detailed imageries of life and function as mediators. In the same manner, the structures and cities create the type of culture and a specific life style, and conserve them. Film enlightens the time it was made and the cultural archeology of the period it depicts", Juhani Pallasmaa (Architect), (Pallasmaa, 2001).

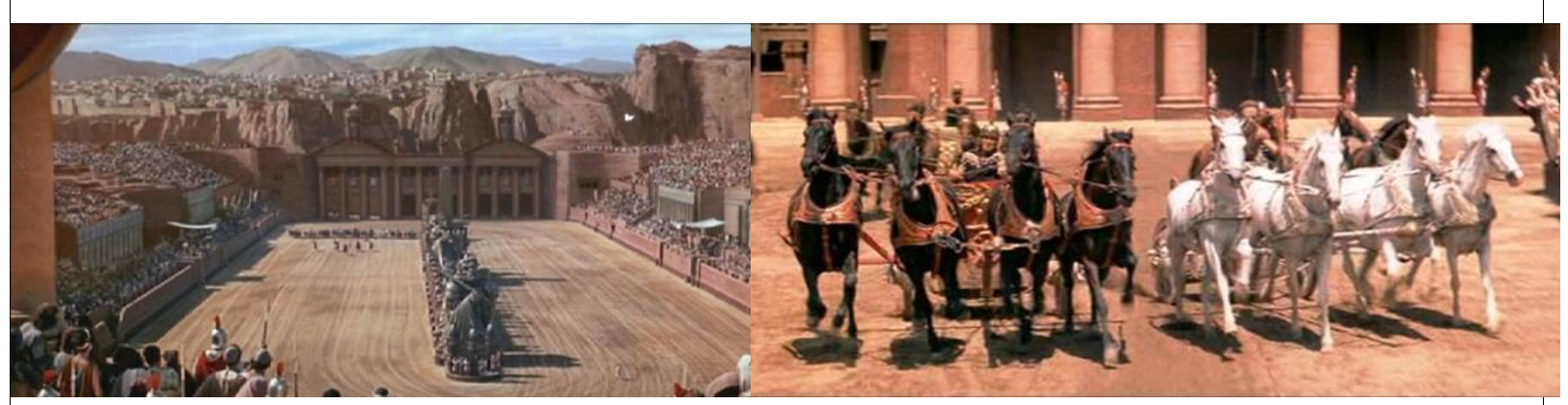

The Spaces that Manifest the Characteristics and Culture of a Period at Cinema and Architecture:

Ben Hur, William Wyler (director), USA, 1959.

Space in architecture is very influential in creating time. What is designed is not time, but space. A change in time defines the space. Space is described as moving from one moment to another in time.

"It is the human who creates the space that he/she moves in and expresses him/herself. Spaces are born and they die, just like societies. Spaces are alive; they have their own history", Pierre Francastel (Art Historian), (Heath, 1986). 


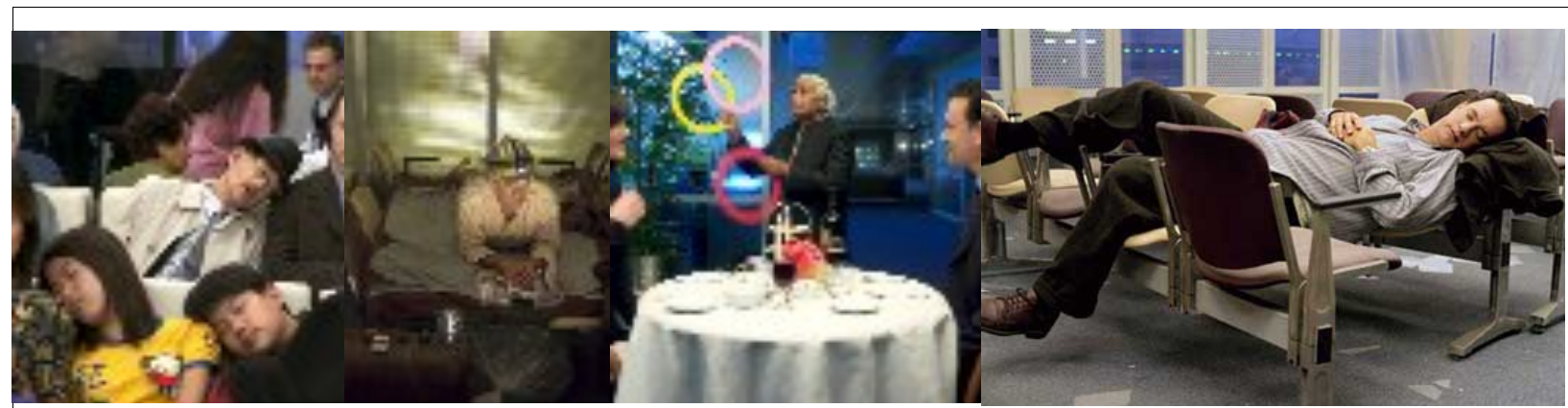

The Spaces that Manifest the Characteristics and Culture of a Period at Cinema and Architecture:

The Terminal, Steven Spielberg (director), USA, 2004.

Time in film, however, is a crucial factor in obtaining the space. Space and time are both designed in film. The identification and the formation of space depend on time; also, the formed space is the evidence of time itself.

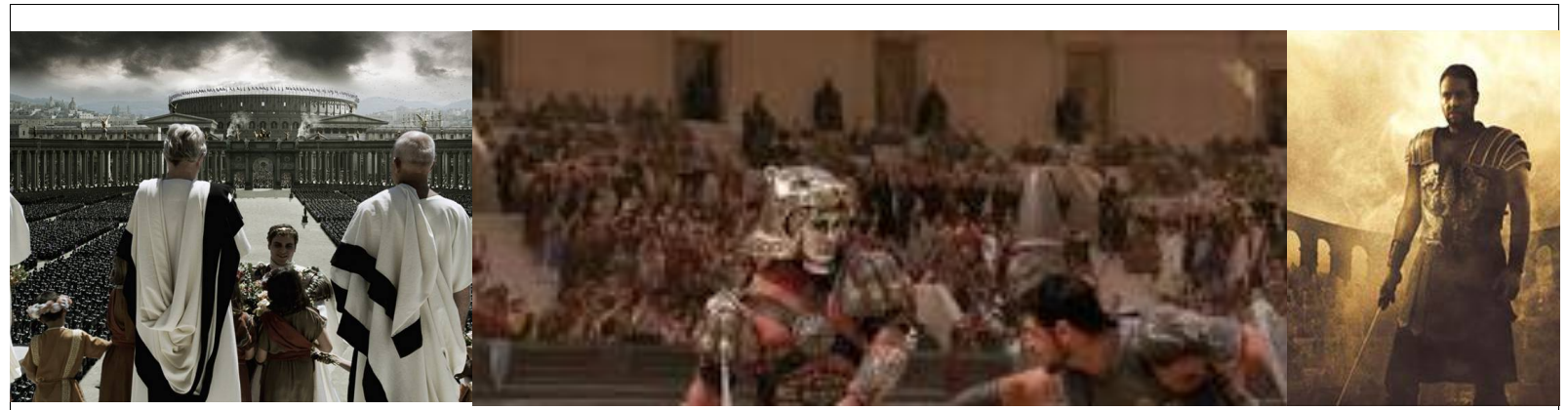

The Spaces and Times that Manifest the Characteristics and Culture of a Period at Cinema and Architecture:

Gladiator, Ridley Scott (director), USA, UK, 2000.|

In a film, the alterations in space transform time, as the alterations in time transform the space. Film is an art of space, as well as of time.

Film establishes the space it requires in two ways: The first is by "using the existing space", while the other is "creating the fictional space", (Ince, 2007).

The existing space can be used by the actors as a stage in compliance with today's conditions, or the real life that already exists in the space can be recorded as it is.

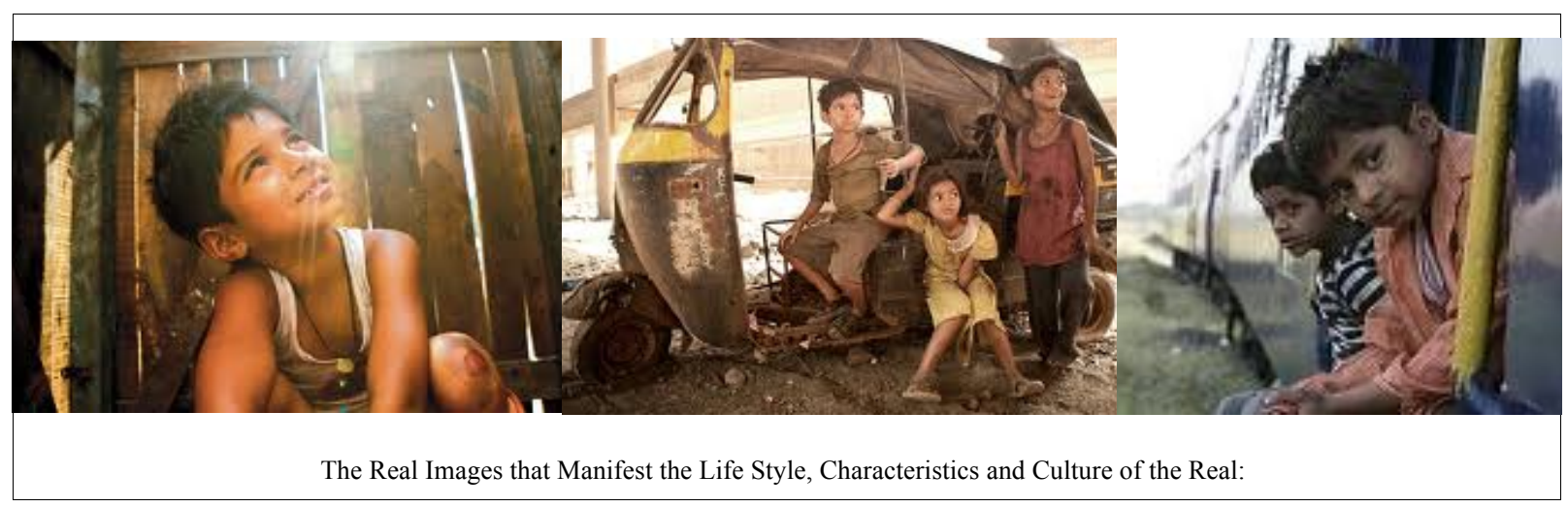


Slumdog Millionare, Danny Boyle, Loveleen Tandan (directors), UK, 2008.

Apart from that, the existing space can be recreated in film sets or the utilization of the space can be changed completely in order to come up with a novel utilization suggestion, depending on the cost, transportation, security, climatic conditions, and the necessary permits.

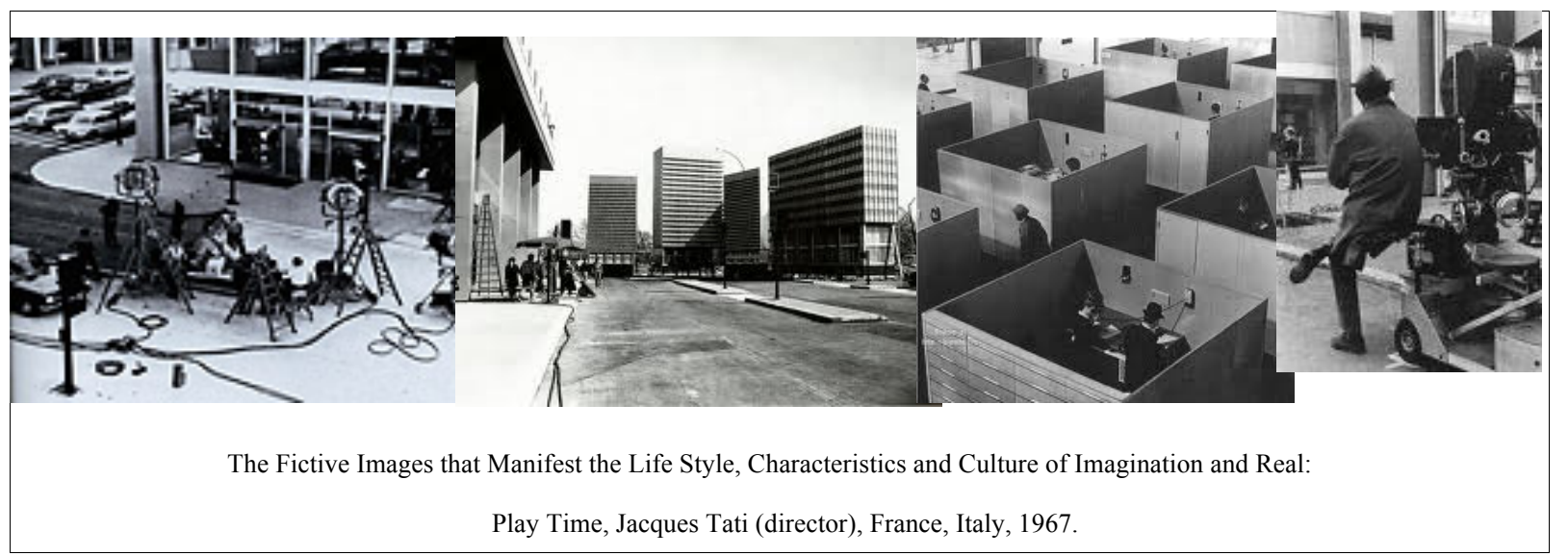

The first films from Lumiere brothers are very good examples for this genre. Additionally, the city imageries that we see in most films are shootings such as these. The life as it is becomes a part of the film with all its dimensions.

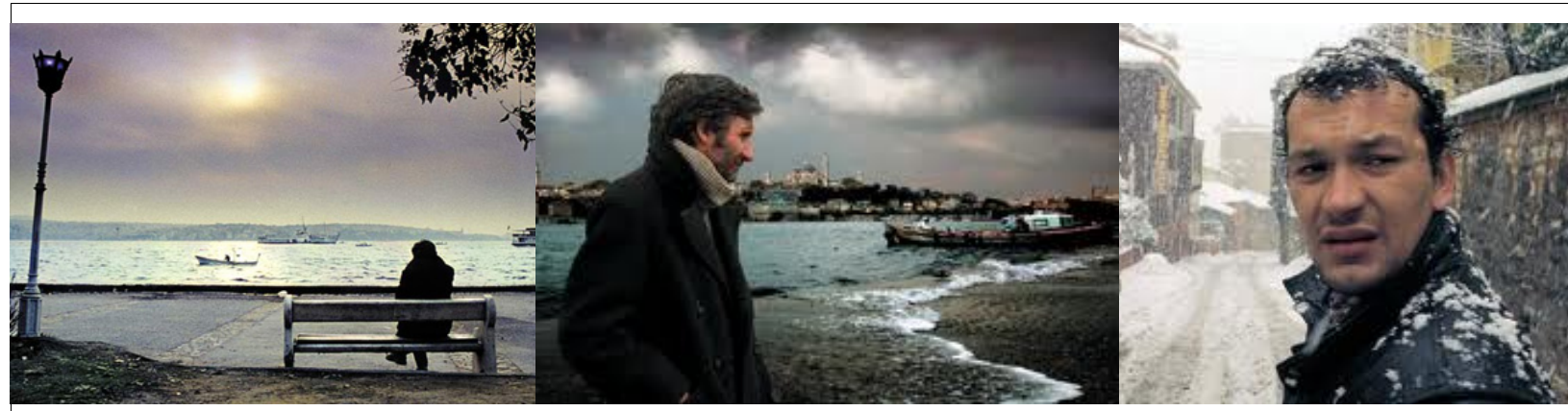

The Real Images that Manifest the Life Style, Characteristics and Culture of 2000's at Istanbul:

Uzak (Distant), Nuri Bilge Ceylan (director), Turkey, 2002.

Another way to utilize the existing space is demonstrated in films that use historical spaces in compliance with the periods these spaces are built.

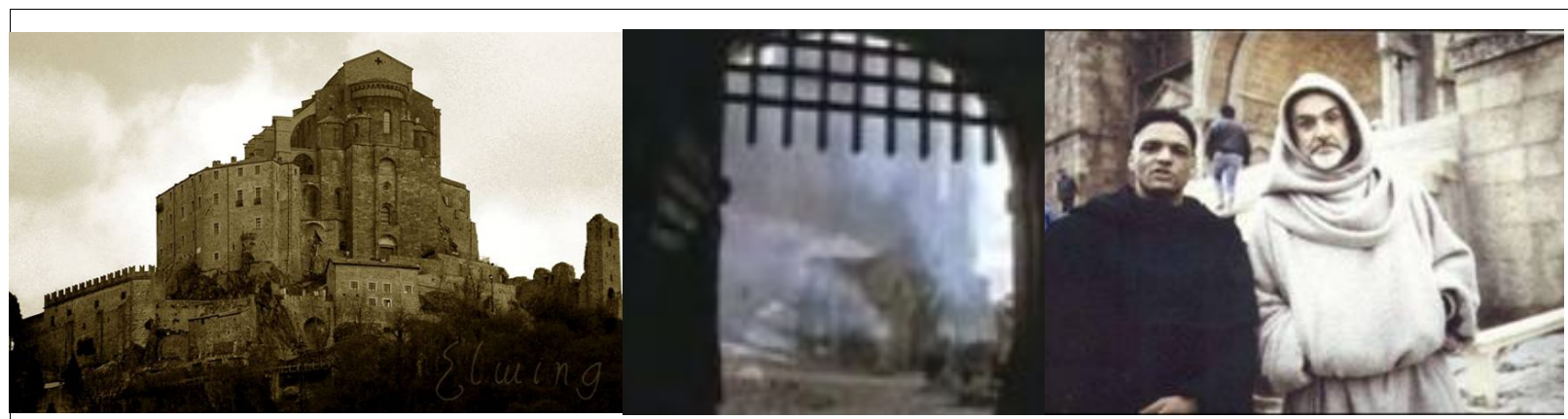

The Spaces and Times that Manifest the Life Style, Characteristics and Culture of a Period at Cinema and Architecture: 
Der Name der Rose (The Name of the Rose), Jean-Jacques Annaud (director), France, Italy, West Germany, 1986.

In film, the formation of space towards the creation of fictional space has been widely applied since the beginning of cinema. In films like that, we go out of the sense of space that prevails, and a completely new architecture and a life style have been designed peculiar to that period.

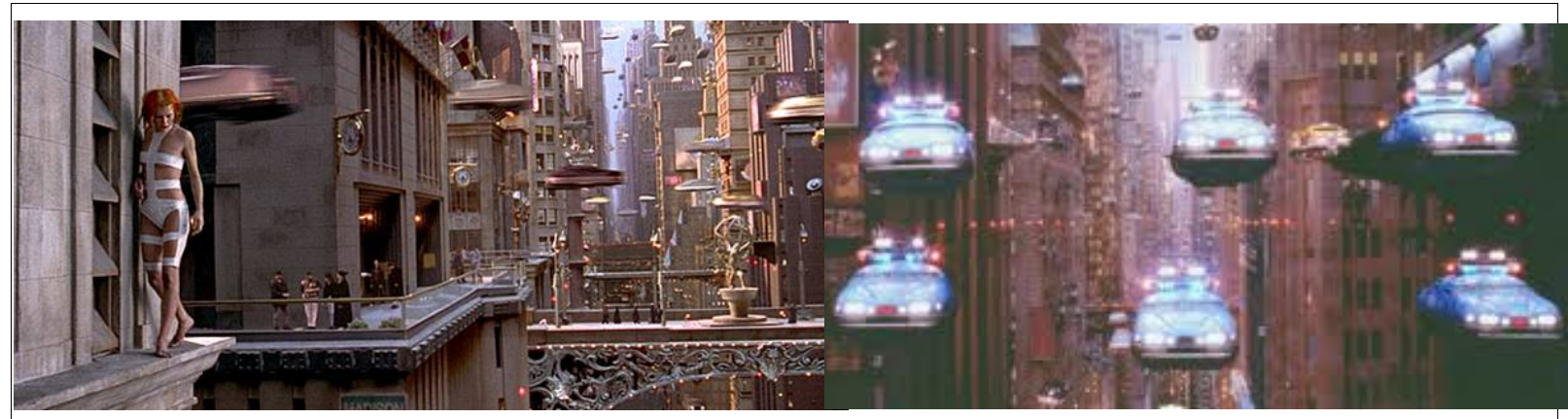

The Fictional Spaces and Times that Manifest the Life Style, Characteristics and Culture of a Period at Cinema and Architecture:

The Fifth Element, Luc Besson (director), France, 1997.

The formation of space towards the creation of fictional space in film demonstrates how architecture changes, that it can change, that it must change under different conditions, in different times, with different users.

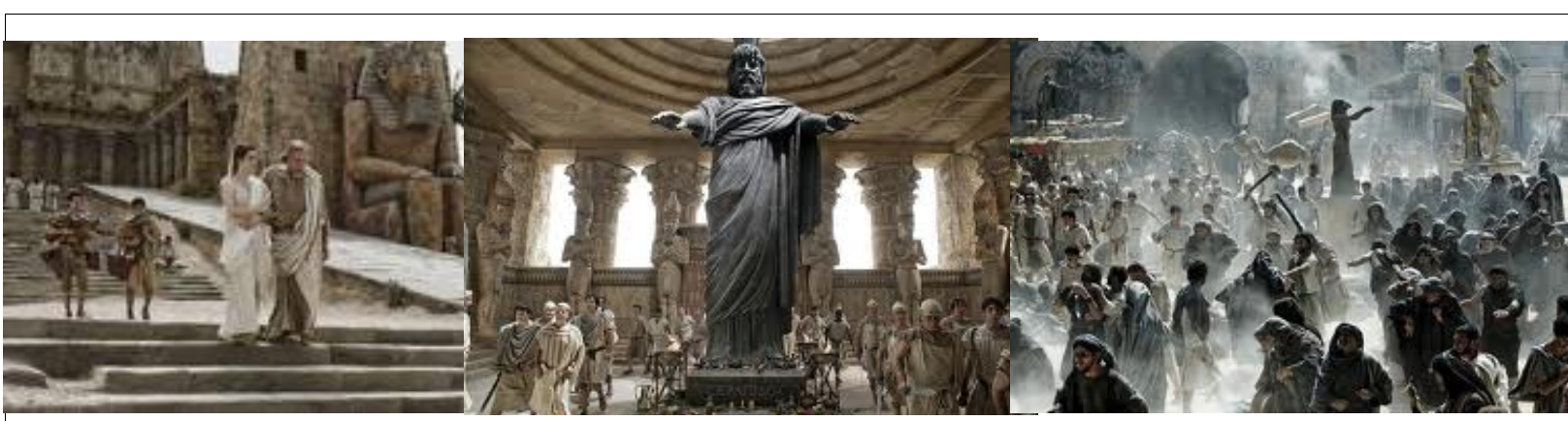

The Fictive Spaces and Times that Manifest the Life Style, Characteristics and Culture of a Period: Alexandria Library, Egypt:

Agora, Alejandro Amenabar (director), Spain, 2009

In addition to these features, films like this can be considered as individual simulations of how spaces, which we encounter as prototypes today, can change the city, the street, or rather life itself.

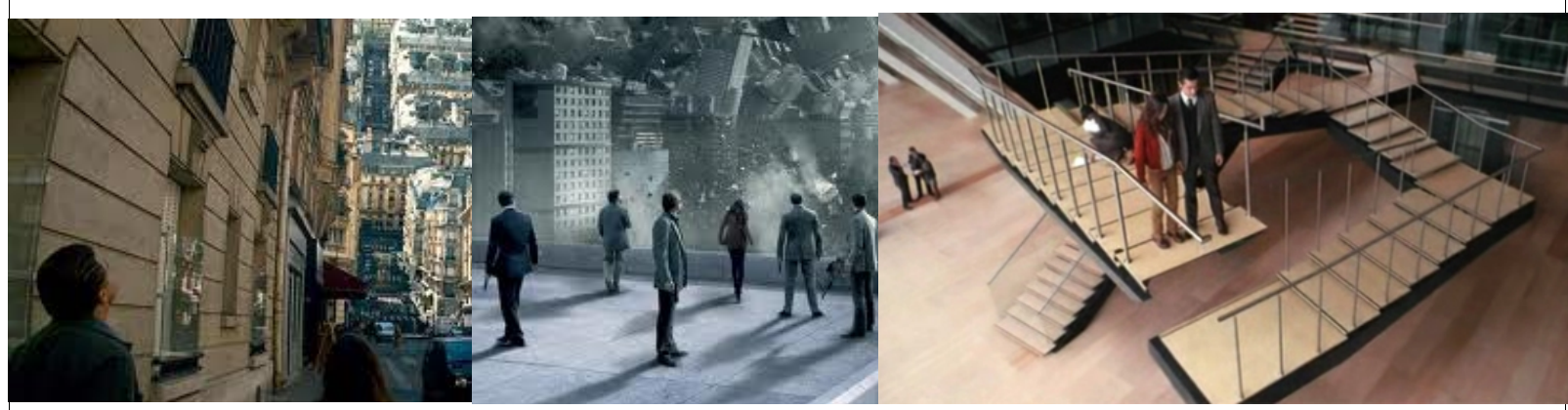

The Imaginative Spaces and Times that Manifest the Life Style, Characteristics and Culture of Dreams at Cinema and Architecture: 
Inception, Christopher Nolan (director), USA, UK, 2010.

As a result, if we look at the forms of using space in film, we witness three different usages of space in film, (Ince, 2007).

In the visual images derived from films that "use space as a background", the space is seen in the background and this is very common in almost all films. Space is used as a background for the events that take place in the foreground; it fills in the emptiness behind the actors.

In films like that, the space is not used as a narration tool, and these films are so far away from sending a spatial message to the audience. Spaces in films are not essential and the elements that enter or leave the space do not make any changes in the course of the film.

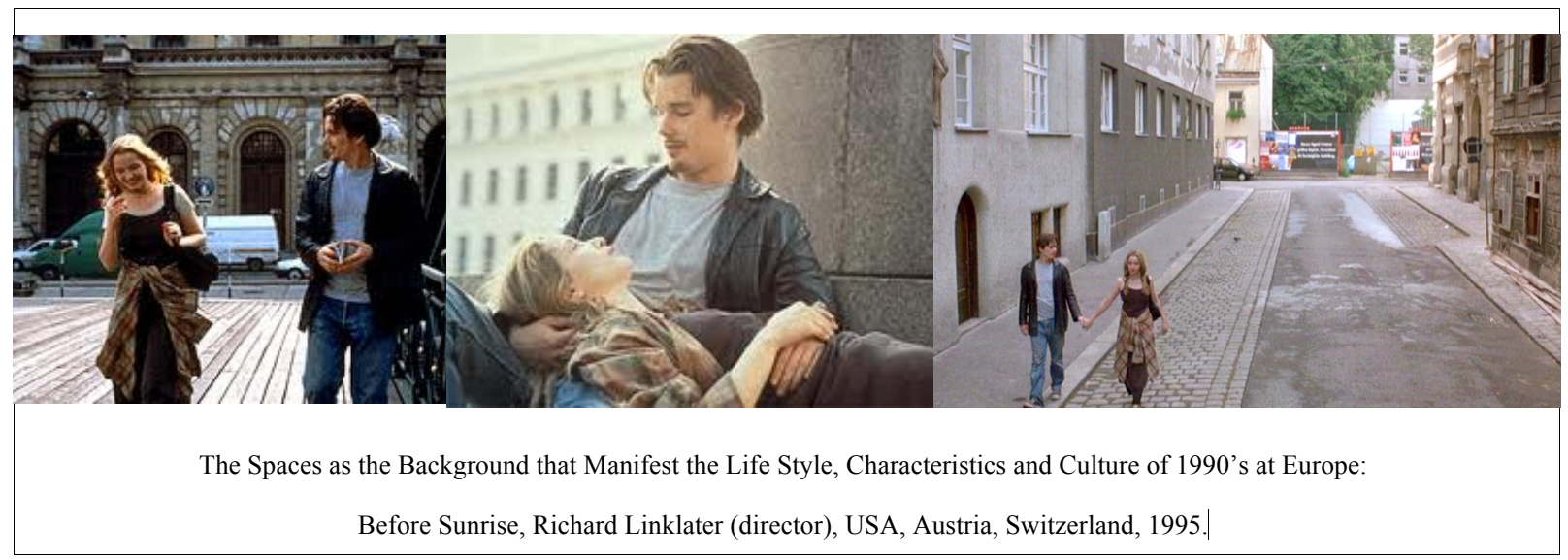

Another usage of space is "using space as a complementary element". The intention here is that the director employs the space just like other cinematic elements, in order to create a specific impression or express a particular idea. Space is used to prepare the audience for the events that will occur in the future. Every space that is shown carries the hints of the coming events.

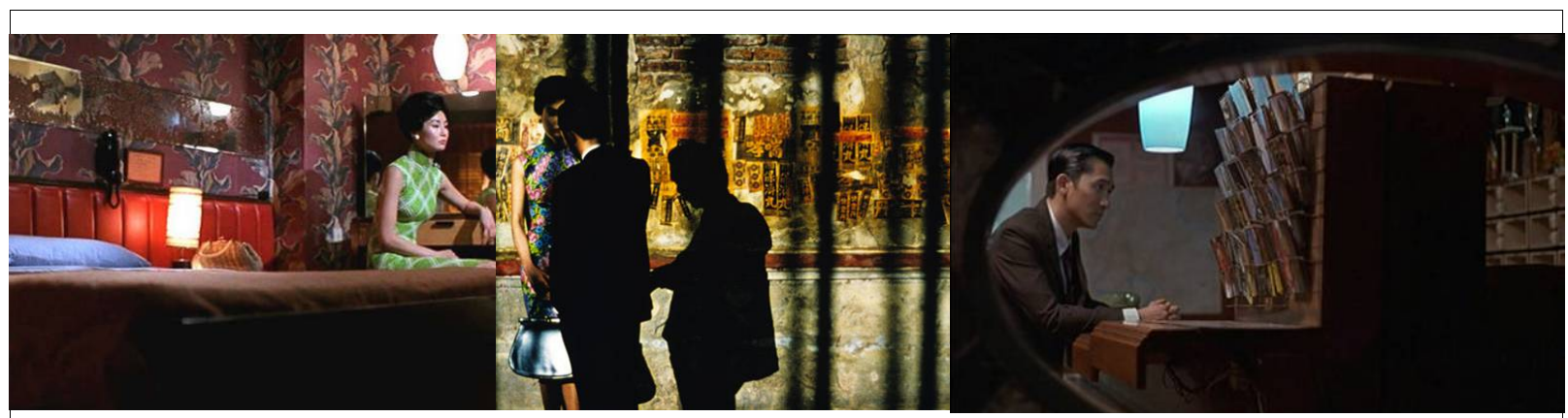

The Spaces as the Complementary Element that Manifest the Life Style, Characteristics and Culture of 2000's at Hong Kong:

In the Mood for Love, Kar Wai Wong (director), Hong Kong, France, 2000.|

Directors that "use the space as the main element" consider the space within the groups of elements on the foreground; they expose the space, analyze and change it. They are interested in demonstrating architecture and the space. 


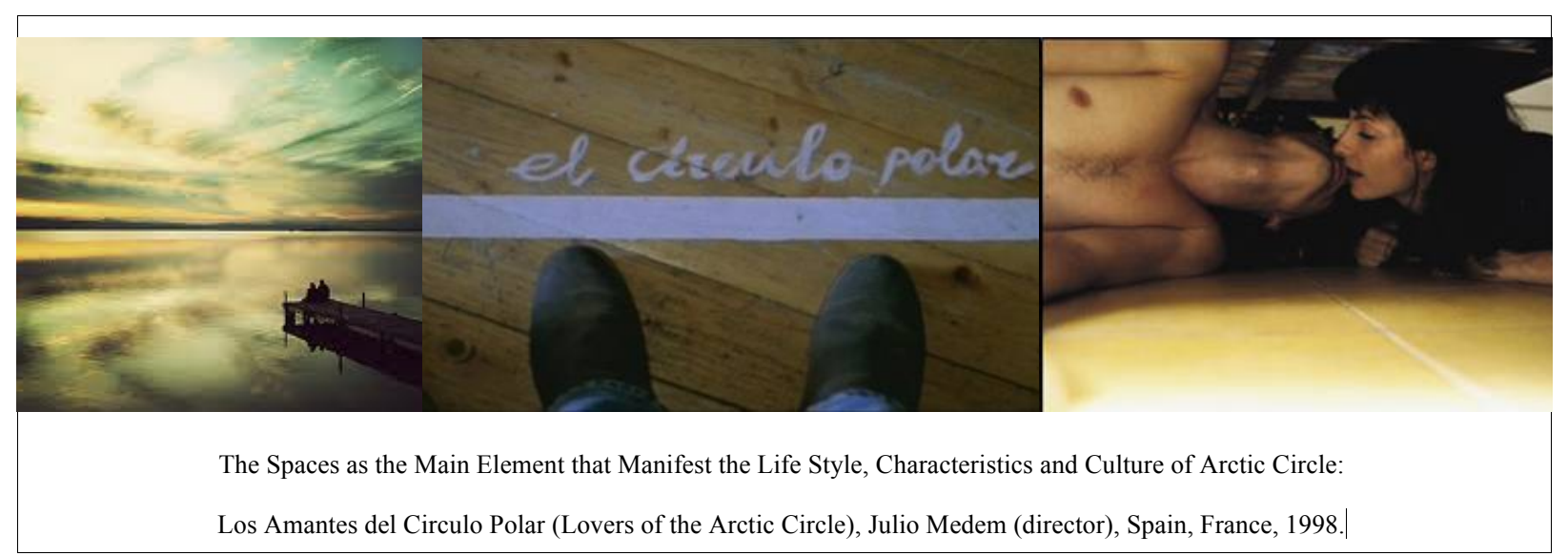

When we look at the films that use the space as the main element, the ones about the cities stand out. As mentioned before the films like that provide the architecture and the social life styles of the cities, cues on the time and future, as well as relationships between problems and their solutions.

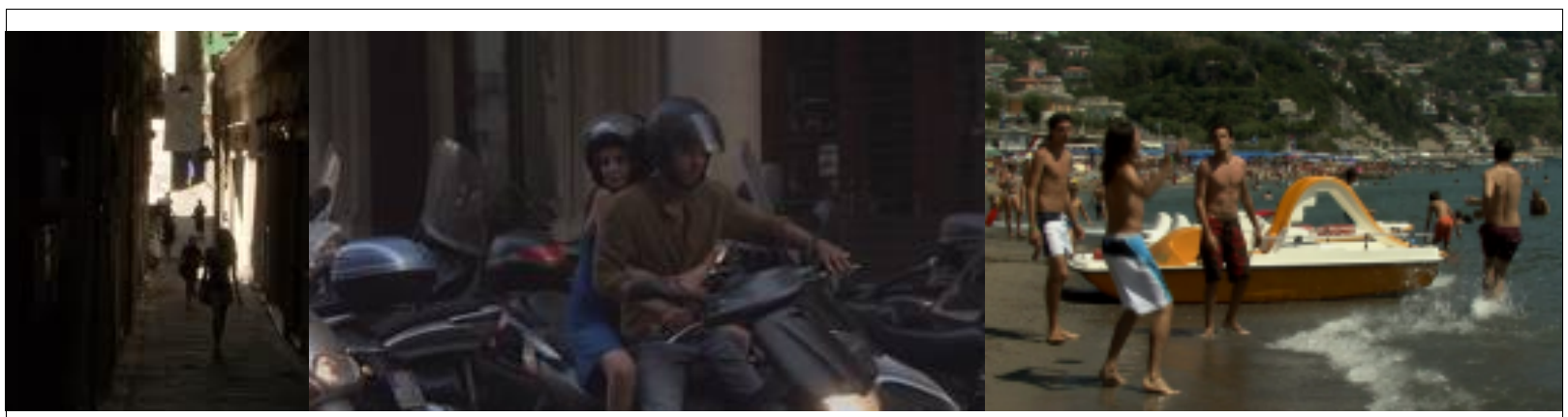

The Spaces as the Main Element that Manifest the Life Style, Characteristics and Culture of 2000's at Genova:

Genova, Michael Winterbottom (director), UK, 2008.

Additionally in films that use the space as the main element, the space takes place on the screen like a leading actor. It becomes an integral part of film.

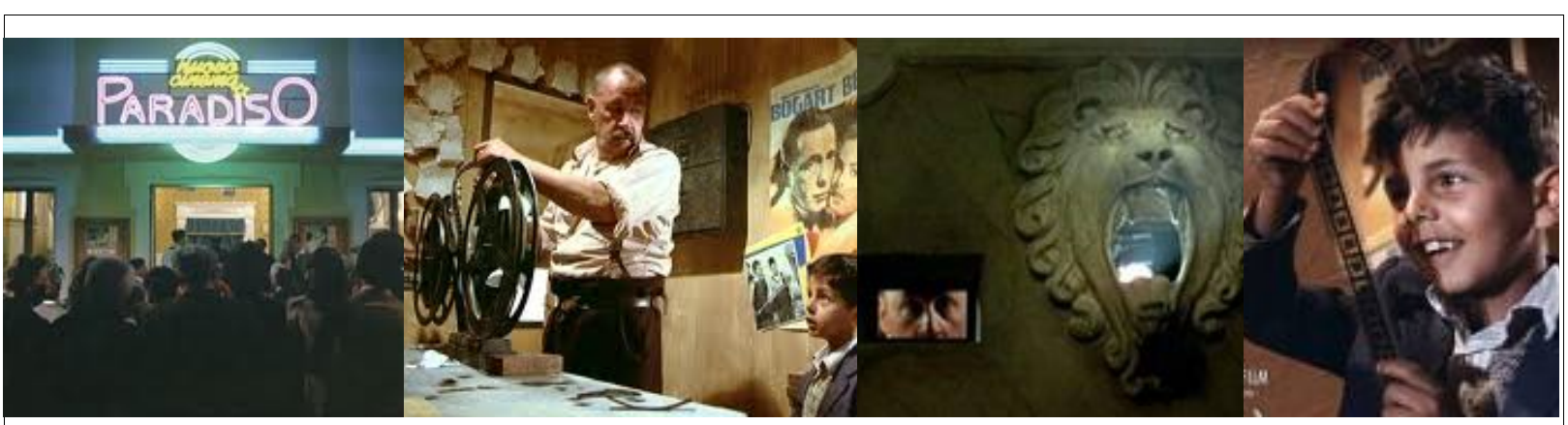

The Spaces as the Main Element that Manifest the Life Style, Characteristics and Culture of Cinema at Cinema and Architecture:

Nuovo Cinema Paradiso (Cinema Paradiso), Giuseppe Tornatore (director), Italy, France, 1988. 


\section{To End: Conclusion}

We cannot talk about culture without human existence. The human existence cannot be comprehended separate from its habitat. To exist, to separate one from the other is equal to be defined as an individual. The most basic definition of space as "the convenient space that separates a man from his environment to a certain extent, and allows him to maintain his deeds inside", (Hasol, 1998) clearly exerts the relationship of space with the being, that is; human.

While man creates a space, he, in one sense, creates his own being as well; and he cannot consider the space he created separate from the culture he possesses. Therefore it can be said that, culture is a significant factor in the formation of space. Architecture, defined as the art of creating space, takes its place within the constituents of culture, and so the space reflects its own culture. As well as architecture, this phenomenon also applies to the field of cinema.

Throughout the history, just like architecture which had seen formal and expressionist changes, the architectural space too, experienced several changes. It was highly influenced by technical innovations, sociopolitical revolutions and philosophical changes; experienced sudden alterations; demonstrated developments in time. Just like the space we have come to observe in cinema.

Space is the most significant element of architecture that brings the different periods and cultures together, and connects the past and future of architecture, (Gur, 1996), (Engels, 1964). Just like the space in the cinemas.

The culture in the cinematic and architectural space, just like it is known from the essential definition of culture, has a process that develops by accumulation and a tendency to expand. It emerges as a system peculiar to human kind, and once it is emerged, it maintains to sustain and complicates itself along with many other areas it is affiliated to, by means of every individual that is born into this world.

Cinematic and architectural works that exist inside the elements of culture also contain the most advanced seeds of change in the moral culture of a society. In other words, the future of a society, with the influence of the material elements of culture, blossoms within the framework of that society's artistic, literary and intellectual activities; it reflects itself on the cinema and architecture. The people in the world of art, literature and thought are, in some ways, the judges of today, and the harbingers of the future. For this reason, they are considered among the most active architects of the future societies. However, we shall not forget that art is an area that defines the most affirmative burgeons and sprays of a society, (Alakus, 2004) and it is included in culture.

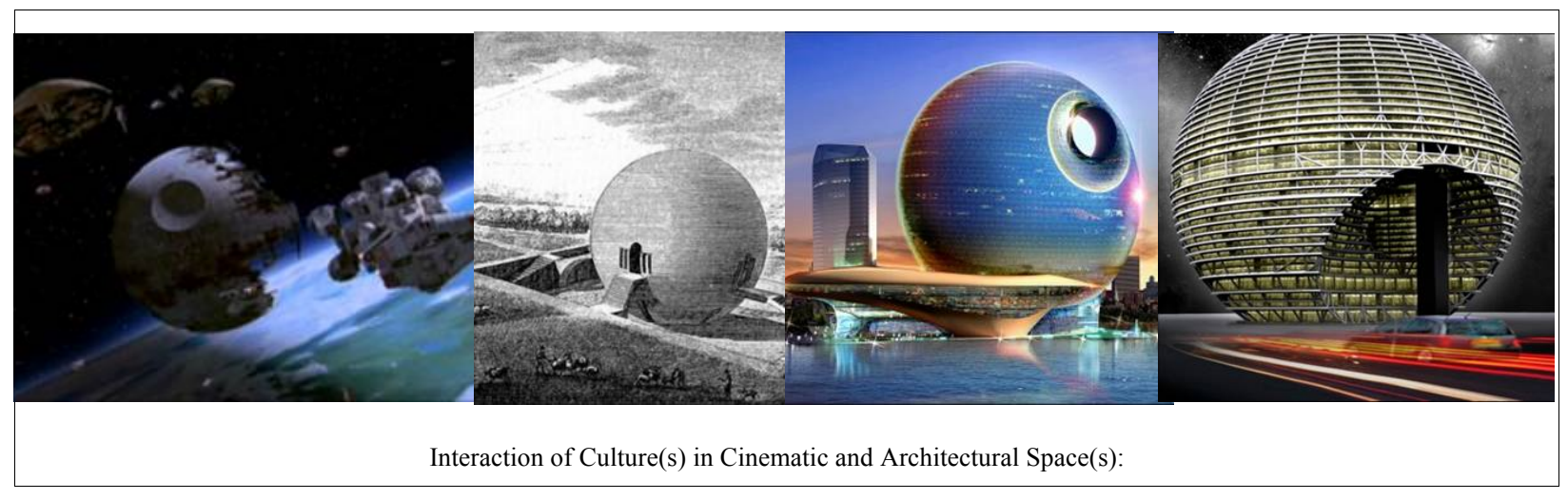


The 2nd Death Star from Star Wars: Episode III-Revenge of the Sith, George Lucas (director), USA, 2005 /

A House Project, Claude-Nicolas Ledoux (architect), Chaux, 1789 /

Death Star Lunar Hotel (Hotel Full Moon), Heerim Architects (architect), Baku, Azerbaijan, 2008 /

RAK Congress Center, OMA (architect), Dubai,United Arab Emirates, 2008.
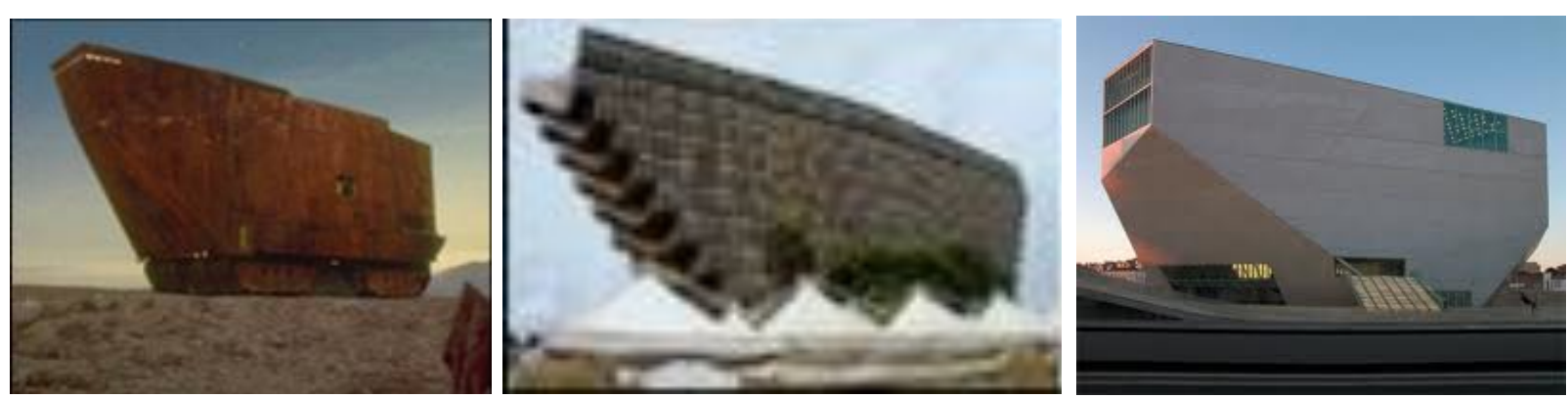

Interaction of Culture(s) in Cinematic and Architectural Space(s):

Jawa Sandcrawler from Star Wars: Episode III-Revenge of the Sith, George Lucas (director), USA, 2005 /

Hotel in Tunis / Casa de Musica, Rem Koolhaas (architect), Porto, 2005.

Art, due to its definition, is decorated with qualities like free, original, new, unique, educational and leader.

"The movies will be the faithful translator of the architect's boldest dreams", Luis Buñuel (Filmmaker), (URL 2).

In this regard, the products of cinema and architecture have acquired and will continue to acquire the nature of the document being as creating and maintaining a memory, that manifest the social, political, economic, cultural changes and transformations within the historical developmental processes. The spaces manifest the culture and will continue to manifest. 


\section{References}

Alakus, A. O., 2004. Kultur Kavrami Tanimlamalarina Iliskin Bir Analiz, Milli Egitim Dergisi, Sayi: 64, Milli Egitim Bakanligi Yayinlari, Ankara.

Dear, M., 1994. Between Architecture and Film, Architecture \& Film, Architectural Design, Maggie Toy, London.

Engels, F., 1964. (Transilated by Hilav, S.) Sosyalist Dusuncenin Gelismesi, Sosyal Yayinlar, Istanbul.

Ergin, S., 2007. Mimarlık ve Sinema Etkilesiminin Sinemasal Mekan Etkileri ve Nuri Bilge Ceylan Sinemasindan Bir Ornek: Uzak, Master Thesis, Anadolu University, Eskisehir.

Ettedgui, P., 1999. Production Design \& Art Direction Screencraft, Focal Press, London.

Guvenc, B., 1985. Kultur Konusu ve Sorunlarimiz, Remzi Kitabevi, Istanbul.

Hasol, D., 1998. Ansiklopedik Mimarlik Sozlugu, Yapi Endustri Merkezi Yayinlari, Istanbul.

Heath, S., 1986. Narrative Space, Narrative, Apparatus, Ideology: A Film Theory Reader, Philip Rosen., Colombia University Press, New York.

Ince, T. E., 2007. Mimarlik Sinema İliksisinin Sokak Mekani Uzerinden Incelenmesi, Master Thesis, Gazi University, Ankara.

Jarvie, I. C. , 1987. Philosophy of The Film: Epistemology, Ontology, Aesthetics, Routledge and Kegan Paul, New York, London.

Monaco, J., 2000. How to Read a Film, Oxford University Press, New York.

Pallasmaa, J., 2001. The Architecture of Image: Existential Space in Cinema, Rakennustieto, Helsinki.

Pelissier, A., Tschumi, B., 1999. The Architecture of Le Fresnoy at the Crossroads of Three Programs, Tschumi Le Fresnoy Architecture in Between, Cornelia Blatter, Marcel Hermans, The Monacelli Press, Inc., New York.

Rapoport, A., 2005. Culture, Architecture, and Design, Locke Science Publishing Company, Inc., Chicago, Illinois, USA.

Sualp, Z. T. A., 2004. Zaman Mekan Kuram ve Sinema, Theoria Dizisi 12, Ali Akay, Baglam Yayınlari, İstanbul.

Tanyeli, U., 2001. Sinema ve Mimarlik: Temsiliyet Nesnenin Temsili Sanatin Sanallikla Ifadesi”, Journal of Arredamento Mimarlik, 11:66.

Tureli, I., 2001. Sinema ve Kentsel Mekanin Dönüsümü, Journal of Arredamento Mimarlik, 11: 71-72.

Turhan, M., 1994. Kultur Degismeleri (Sosyal Psikoloji Bakimindan Bir Teknik), Marmara Universitesi Ilahiyat Fakultesi Vakfi Yayinlari, Istanbul.

Tschumi, B., 2000. Event Cities 2, The MIT Press, London.

URL 1. http://www.fantastikedebiyat.com/sinemanin_kisa_tarihi_i-132-sinema-yazi.html (May 2011). 
URL 2. http://www.thearchitectpainter.com/ARLINGTON/cinematecture.html (May 2011).

Vidler, A., 2001. Warped Space; Art, Architecture, and Anxiety in Modern Culture, The MIT Press, London, England. 